\title{
Temperate southern Australian coastal waters are characterised by surprisingly high rates of nitrogen fixation and diversity of diazotrophs
}

\author{
Lauren F Messer ${ }^{1,2}$, Mark V Brown ${ }^{3}$, Paul D van Ruth ${ }^{4}$, Mark Doubell ${ }^{4}$, Justin R Seymour ${ }^{\text {Corresp. } 1}$ \\ ${ }^{1}$ Climate Change Cluster, University of Technology Sydney, Sydney, New South Wales, Australia \\ 2 Centre for Microbiome Research, School of Biomedical Sciences, Queensland University of Technology, Brisbane, QLD, Australia \\ ${ }^{3}$ School of Environmental and Life Sciences, University of Newcastle, Callaghan, New South Wales, Australia \\ 4 Aquatic Sciences, South Australian Research and Development Institute, Adelaide, South Australia, Australia \\ Corresponding Author: Justin R Seymour \\ Email address: Justin.Seymour@uts.edu.au
}

Biological dinitrogen $\left(\mathrm{N}_{2}\right)$ fixation is one mechanism by which specific microorganisms (diazotrophs) can ameliorate nitrogen (N) limitation. Historically, rates of $\mathrm{N}_{2}$ fixation were believed to be limited outside of the low nutrient tropical and subtropical open ocean, however, emerging evidence suggests that $\mathrm{N}_{2}$ fixation is also a significant process within temperate coastal waters. Using a combination of amplicon sequencing, targeting the nitrogenase reductase gene (nifH), quantitative nifH PCR, and ${ }^{15} \mathrm{~N}_{2}$ stable isotope tracer experiments, we investigated spatial patterns of diazotroph assemblage structure and $\mathrm{N}_{2}$ fixation rates within the temperate coastal waters of southern Australia during Austral autumn and summer. Relative to previous studies in open ocean environments, including tropical northern Australia, and tropical and temperate estuaries, our results indicate that high rates of $\mathrm{N}_{2}$ fixation (10 - $64 \mathrm{nmol} \mathrm{L}^{-1} \mathrm{~d}^{-1}$ ) can occur within the large inverse estuary Spencer Gulf, while comparatively low rates of $\mathrm{N}_{2}$ fixation $\left(2 \mathrm{nmol} \mathrm{L}^{-1} \mathrm{~d}^{-1}\right)$ were observed in the adjacent continental shelf waters. Across the dataset, low concentrations of $\mathrm{NO}_{3} / \mathrm{NO}_{2}$ were significantly correlated with the highest $\mathrm{N}_{2}$ fixation rates, suggesting that $\mathrm{N}_{2}$ fixation could be an important source of new $\mathrm{N}$ in the region as dissolved inorganic $\mathrm{N}$ concentrations are typically limiting. Overall, the underlying diazotrophic community was dominated by nifH sequences from Cluster 1 unicellular cyanobacteria of the UCYN-A clade, as well as non-cyanobacterial diazotrophs related to Pseudomonas stutzeri, and Cluster 3 sulfate-reducing deltaproteobacteria. Diazotroph community composition was significantly influenced by salinity and $\mathrm{SiO}_{4}$ concentrations, reflecting the transition from UCYN-A-dominated assemblages in the continental shelf waters, to Cluster 3-dominated 
assemblages in the hypersaline waters of the inverse estuary. Diverse, transitional diazotrophic communities, comprised of a mixture of UCYN-A and putative heterotrophic bacteria, were observed at the mouth and southern edge of Spencer Gulf, where the highest $\mathrm{N}_{2}$ fixation rates were observed. In contrast to observations in other environments, no seasonal patterns in $\mathrm{N}_{2}$ fixation rates and diazotroph community structure were apparent. Collectively, our findings are consistent with the emerging view that $\mathrm{N}_{2}$ fixation within temperate coastal waters is a previously overlooked dynamic and potentially important component of the marine $\mathrm{N}$ cycle. 
1 Temperate southern Australian coastal waters are

2 characterised by surprisingly high rates of nitrogen

3 fixation and diversity of diazotrophs

4

5

6

7 Seymour $^{2 *}$

${ }^{1}$ Centre for Microbiome Research, School of Biomedical Sciences, Queensland University of

11 Technology, Brisbane, Queensland, Australia

${ }^{2}$ Climate Change Cluster, University of Technology Sydney, Sydney, New South Wales, Australia

$14{ }^{3}$ School of Environmental and Life Sciences, University of Newcastle Australia, Callaghan, 15 New South Wales, Australia

$16{ }^{4}$ Aquatic Sciences, South Australian Research and Development Institute, Adelaide, South

17 Australia, Australia

18

19

20

21

22

23

24

25

26

27

28

29

30

31

32

33

34

35

36

37
*Corresponding Author:

Justin R. Seymour ${ }^{2}$

Email address: justin.seymour@uts.edu.au

Lauren F. Messer ${ }^{1,2}$, Mark V. Brown ${ }^{3}$, Paul D. van Ruth ${ }^{4}$, Mark Doubell ${ }^{4}$, and Justin R.

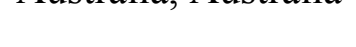


39

40

41

42

43

44

45

46

47

48

49

50

51

52

53

54

55

56

57

58

59

60

61

62

63

64

65

66

67

68

69

70

71

72

73

74

75

76

77

\section{Abstract}

Biological dinitrogen $\left(\mathrm{N}_{2}\right)$ fixation is one mechanism by which specific microorganisms (diazotrophs) can ameliorate nitrogen $(\mathrm{N})$ limitation. Historically, rates of $\mathrm{N}_{2}$ fixation were believed to be limited outside of the low nutrient tropical and subtropical open ocean, however, emerging evidence suggests that $\mathrm{N}_{2}$ fixation is also a significant process within temperate coastal waters. Using a combination of amplicon sequencing, targeting the nitrogenase reductase gene (nifH), quantitative nifH PCR, and ${ }^{15} \mathrm{~N}_{2}$ stable isotope tracer experiments, we investigated spatial patterns of diazotroph assemblage structure and $\mathrm{N}_{2}$ fixation rates within the temperate coastal waters of southern Australia during Austral autumn and summer. Relative to previous studies in open ocean environments, including tropical northern Australia, and tropical and temperate estuaries, our results indicate that high rates of $\mathrm{N}_{2}$ fixation $\left(10-64 \mathrm{nmol} \mathrm{L}^{-1} \mathrm{~d}^{-1}\right)$ can occur within the large inverse estuary Spencer Gulf, while comparatively low rates of $\mathrm{N}_{2}$ fixation $\left(2 \mathrm{nmol} \mathrm{L}^{-1}\right.$ $\mathrm{d}^{-1}$ ) were observed in the adjacent continental shelf waters. Across the dataset, low concentrations of $\mathrm{NO}_{3} / \mathrm{NO}_{2}$ were significantly correlated with the highest $\mathrm{N}_{2}$ fixation rates, suggesting that $\mathrm{N}_{2}$ fixation could be an important source of new $\mathrm{N}$ in the region as dissolved inorganic $\mathrm{N}$ concentrations are typically limiting. Overall, the underlying diazotrophic community was dominated by nifH sequences from Cluster 1 unicellular cyanobacteria of the UCYN-A clade, as well as non-cyanobacterial diazotrophs related to Pseudomonas stutzeri, and Cluster 3 sulfate-reducing deltaproteobacteria. Diazotroph community composition was significantly influenced by salinity and $\mathrm{SiO}_{4}$ concentrations, reflecting the transition from UCYN-A-dominated assemblages in the continental shelf waters, to Cluster 3-dominated assemblages in the hypersaline waters of the inverse estuary. Diverse, transitional diazotrophic communities, comprised of a mixture of UCYN-A and putative heterotrophic bacteria, were observed at the mouth and southern edge of Spencer Gulf, where the highest $\mathrm{N}_{2}$ fixation rates were observed. In contrast to observations in other environments, no seasonal patterns in $\mathrm{N}_{2}$ fixation rates and diazotroph community structure were apparent. Collectively, our findings are consistent with the emerging view that $\mathrm{N}_{2}$ fixation within temperate coastal waters is a previously overlooked dynamic and potentially important component of the marine $\mathrm{N}$ cycle.

\section{Introduction}

By providing a source of new nitrogen $(\mathrm{N})$, dinitrogen $\left(\mathrm{N}_{2}\right)$ fixation, the microbially mediated conversion of $\mathrm{N}_{2}$ gas to ammonia, represents a fundamental process within oligotrophic marine environments (Eugster and Gruber, 2012; Karl et al., 2012). Based on global ocean estimates, the activity of $\mathrm{N}_{2}$ fixing microorganisms (termed diazotrophs) contributes approximately $160 \mathrm{Tg}$ of new $\mathrm{N}$ to the ocean annually (Wang et al., 2019). However, the majority of empirical observations contributing towards global $\mathrm{N}_{2}$ fixation estimates have been derived from tropical and subtropical oceanic gyres (Luo et al., 2012), which have traditionally been deemed the principal ecological niche for marine $\mathrm{N}_{2}$ fixation due to the activity of large filamentous and heterocystous cyanobacterial diazotrophs (Breitbarth et al., 2007; Goebel et al., 2010; Karl et al., 
2002). In contrast, temperate coastal habitats have generally been thought to be enriched in dissolved inorganic $\mathrm{N}$ derived from terrestrial and upwelled sources (Jickells, 1998), thereby restricting the niche for biological $\mathrm{N}_{2}$ fixation.

Temperate coastal waters are some of the most productive regions on Earth, which have historically been believed to be fuelled by the influx of bioavailable nutrients from rivers, groundwater, and through the mixing of offshore waters (Jickells, 1998). Often these hydrodynamic properties result in the development and maintenance of relatively eutrophic conditions, which in combination with typically cool sea surface temperatures, resulted in the supposition that diazotrophic growth and activity, particularly for the large filamentous cyanobacterium Trichodesmium sp., would be limited (Breitbarth et al., 2007; Howarth et al., 1988; Knapp, 2012). However, largely due to the newly recognised abundance and activity of non-cyanobacterial diazotrophs and unicellular cyanobacteria (UCYN) outside of the traditional oceanic niches of $\mathrm{N}_{2}$ fixation, there has been a recent paradigm shift in the potential importance of $\mathrm{N}_{2}$ fixation in temperate coastal regions, where annual $\mathrm{N}_{2}$ fixation rates have been estimated to exceed $16 \mathrm{Tg} \mathrm{N}$ (Tang et al., 2019b). Therefore, an enhanced understanding of $\mathrm{N}_{2}$ fixation rates and patterns in diazotroph diversity and activity within temperate coastal habitats is required to inform models of marine $\mathrm{N}$ availability at regional and global scales.

The widespread application of molecular surveys targeting the gene encoding a subunit of the nitrogenase enzyme complex ( $n i f H$ ), have greatly expanded the known diversity and global distribution of numerically important diazotrophs (Cornejo-Castillo et al., 2018; Farnelid et al., 2011; Langlois et al., 2015; Moisander et al., 2010; Zehr et al., 1998, 2000, 2003). For example, nifH containing UCYN clades, Candidatus Atelocyanobacterium thalassa (UCYN-A), UCYN-B, and UCYN-C, and putative heterotrophic, non-cyanobacterial diazotrophs, from the gamma-, delta-, and alphaproteobacteria, have recently been detected throughout the major ocean basins (Díez et al., 2012; Farnelid et al., 2013; Fernández-Méndez et al., 2016; Gradoville et al., 2017; Langlois et al., 2015). Investigations into the ecology of these novel diazotrophs have revealed a range of physiologies and patterns of biogeography. Both free-living (e.g. UCYN-B, and C; Zehr et al., 2001; Taniuchi et al., 2012; Stenegren et al., 2018) and symbiotic (e.g. UCYN-A) UCYN groups have been identified, and evidence suggests a diversity of closely related sub-lineages are representative of distinct ecological niches typically associated with "open ocean" (e.g. UCYNA1) and "coastal" (e.g. UCYN-A2) environments (Cornejo-Castillo et al., 2018; Farnelid et al., 2016; Thompson et al., 2014).

The isolation of non-cyanobacterial diazotrophs from specific habitats, such as the Peruvian oxygen minimum zone (Martinez-Perez et al., 2018), and estuarine waters of the Baltic Sea (Bentzon-Tilia et al., 2014; Farnelid et al., 2014), imply relatively specialised niches for these organisms. However, genomic analysis of isolates, and metagenome-assembled genomes from the alphaproteobacteria and Planctomycetes, have revealed the metabolic flexibility of these 
118 groups, particularly in regard to their $\mathrm{N}$ cycling capabilities (Delmont et al., 2018; Martinez119 Perez et al., 2018). Non-cyanobacterial diazotrophs are distributed throughout tropical and 120 temperate latitudes and are sometimes the dominant members of diazotrophic communities 121 (Bombar et al., 2016; Delmont et al., 2018; Langlois et al., 2015; Moisander et al., 2014). 122 Notably, both non-cyanobacterial diazotrophs and UCYN have recently been identified as 123 important constituents of temperate and coastal diazotroph communities (Bentzon-Tilia et al., 2015b; Messer et al., 2015; Mulholland et al., 2012; Needoba et al., 2007; Rees et al., 2009; Shiozaki et al., 2015a; Short and Zehr, 2007), with their presence often associated with high rates of $\mathrm{N}_{2}$ fixation (Bentzon-Tilia et al., 2015b; Tang et al., 2019b).

In the coastal waters surrounding the Australian continent, bioavailable sources of $\mathrm{N}$ are regularly depleted (Condie and Dunn, 2006). Significant rates of $\mathrm{N}_{2}$ fixation have been observed throughout much of the tropical northern seas surrounding Australia (Bonnet et al., 2015; Messer et al., 2016, 2017; Montoya et al., 2004; Raes et al., 2014) and in the subtropical waters of the eastern Indian Ocean (Raes et al., 2015). High levels of diversity in nifH phylotypes have been detected throughout these regions, including important contributions by Trichodesmium erythraeum, UCYN-A, and the gammaproteobacterial group, Gamma A (Moisander et al., 2014; Bonnet et al., 2015; Messer et al., 2017). In contrast, our understanding of the importance of $\mathrm{N}_{2}$ fixation within the temperate waters along the southern coastline of Australia, which are dominated by large inverse estuaries, is severely limited.

Inverse estuaries represent unique ecosystems within the coastal zone of arid climates (Eyre, 1998), where an excess of evaporation over precipitation results in the formation of strong positive salinity gradients from marine at the mouth to hypersaline at the head (Nunes Vaz et al., 1990; Pritchard, 1952). In contrast to classical estuaries, inverse estuaries receive little to no freshwater input (Eyre, 1998; Smith and Veeh, 1989), and can become seasonally isolated from the adjacent continental shelf-waters when density fronts restrict oceanic inflow at the mouth (Petrusevics et al., 2011). Consequently, inverse estuaries can experience relatively oligotrophic conditions, giving rise to nutrient limitation in some systems (Middleton et al., 2013; Smith and Veeh, 1989).

Previously, we detected the presence of UCYN-A sub-lineages, UCYN-A1 and UCYN-A2, within the inverse estuary Spencer Gulf (Messer et al., 2015), an ecologically and economically important region of the south Australian marine environment (Deloitte Access Economics, 2017). Despite the fact that Spencer Gulf is typically oligotrophic, and primary production is reportedly N limited (Middleton et al., 2013), productive aquaculture industries and commercial fisheries are housed within the region, and the shallow waters act as foraging and nursery grounds for $>30$ species of threatened, protected, and iconic marine macro-organisms (Robbins et al., 2017). Seagrass-based $\mathrm{N}_{2}$ fixation has historically been suspected to be an important source of new $\mathrm{N}$ in the shallow upper region (Smith and Veeh, 1989), however, how pelagic 
158

159

160

161

162

163

164

165

166

167

168

169

170

171

172

173

174

175

176

177

178

179

180

181

182

183

184

185

186

187

188

189

190

191

192

193

194

195

196

197

productivity is maintained within the low-nutrient waters of Spencer Gulf remains an open question. To test the hypothesis that $\mathrm{N}_{2}$ fixation is a significant process within the temperate coastal waters of southern Australia, we investigated spatial and seasonal dynamics of $\mathrm{N}_{2}$ fixation activity, and diazotroph diversity, in Spencer Gulf and the surrounding shelf waters.

\section{Materials \& Methods}

\section{Sample collection}

Surface seawater samples were collected from Spencer Gulf, a large inverse estuary within the South Australian Gulf System ( $\left.22000 \mathrm{~km}^{2}\right)$, and from adjacent continental shelf waters. Spencer Gulf is characterised by steep gradients in sea surface temperatures and salinity and demonstrates marked differences in physicochemical characteristics during autumn/winter and spring/summer (Nunes and Lennon, 1986; Nunes Vaz et al., 1990; Petrusevics, 1993). Therefore, samples were collected during two contrasting seasons, in the Austral autumn between $28^{\text {th }}$ April - $8^{\text {th }}$ May 2014, and in the Austral summer between $2^{\text {nd }}-9^{\text {th }}$ December 2014. Although considered oligotrophic, Spencer Gulf hosts productive aquaculture industries, which have been implicated in localised nutrient enrichment (Fernandes et al., 2007; Lauer et al., 2009). To capture local environmental variability, sampling was performed along a latitudinal gradient within the estuary, from an offshore site situated near Kangaroo Island [35.84S, 136.45E] on the continental shelf, through to the hypersaline region in the north of Spencer Gulf. Four locations inside Spencer Gulf were selected, including, Spencer Gulf mouth [35.25S, 136.69E] and three locations along the edge of the basin, southern Gulf [34.377S, 136.11E], mid-Gulf [33.92S, 136.58E] and northern Gulf [33.04S, 137.59E] (Figure 1).

Sampling at the mouth and shelf sites were conducted from on-board the $R V$ Ngerin in conjunction with routine monitoring for the Southern Australian node of the Integrated Marine Observing System (IMOS). Samples were collected at the Kangaroo Island National Reference Station (NRSKAI; referred to as "shelf” hereafter), and SAM8SG mooring locations (referred to as "mouth" hereafter) (Lynch et al., 2014). A shore-based sampling protocol was adopted for the southern, mid, and northern Gulf sampling sites, whereby surface samples were collected from jetties (piers), approximately 227, 154 and $440 \mathrm{~m}$ from the shore, respectively. In all cases, $60 \mathrm{~L}$ of water was collected from $\sim 1 \mathrm{~m}$ below the surface using a plastic bucket. Buckets and sample storage carboys were rinsed three times with sample water prior to filling and washed with $10 \%$ $\mathrm{HCl}$ and MilliQ between stations. The temperature and salinity of each sample was immediately recorded using a multi-parameter portable meter (WTW Profiline Multi 3320; Xylem Analytics, Germany).

\section{Dissolved inorganic nutrient analyses}

To determine ambient concentrations of dissolved inorganic nutrients, including $\mathrm{NO}_{3}{ }^{-}+\mathrm{NO}_{2}{ }^{-}$, $\mathrm{PO}_{4}{ }^{3-}$ and $\mathrm{SiO}_{4}{ }^{4-}$ (hereafter referred to as $\mathrm{NO}_{3} / \mathrm{NO}_{2}, \mathrm{PO}_{4}$, and $\mathrm{SiO}_{4}$ respectively), subsamples (45 
198

199

200

201

202

203

204

205

206

207

208

209

210

211

212

213

214

215

216

217

218

219

220

221

222

223

224

225

226

227

228

229

230

231

232

233

234

235

236

237

$\mathrm{ml}$ ) were collected in triplicate $50 \mathrm{ml}$ Falcon tubes from each sampling site. Samples were immediately frozen at $-20^{\circ} \mathrm{C}$ and kept frozen prior to analysis. A Flow Injection Analyser (Lachat QuikChem 8000) was used to determine concentrations of $\mathrm{NO}_{3} / \mathrm{NO}_{2}, \mathrm{PO}_{4}, \mathrm{SiO}_{4}$ in the $<$ $0.45 \mu \mathrm{m}$ filtrate from each thawed sample, with a limit of detection of $0.01 \mu \mathrm{M}$.

\section{Particulate carbon, nitrogen, and $\delta^{15} \mathrm{~N}$ analyses}

To provide an estimate of the concentrations of particulate carbon (C) and $\mathrm{N}$ in the planktonic material and the natural abundance of the ${ }^{15} \mathrm{~N}$ isotope in particulate matter $\left(\delta^{15} \mathrm{~N}, \mathrm{~N}_{2}\right.$ fixation incubation $\mathrm{T}_{0}$ ), subsamples of between $2-4 \mathrm{~L}$ of surface seawater were collected from each site. Subsamples were filtered onto GF/F grade $0.7 \mu \mathrm{m}$ filters (Whatman, Kent, UK) which were previously individually packaged in aluminium foil and pre-combusted at $450{ }^{\circ} \mathrm{C}$ for $4 \mathrm{~h}$. Samples were stored double contained in two snap-lock bags and kept frozen at $-20^{\circ} \mathrm{C}$, prior to being dried for $48 \mathrm{~h}$ at $60^{\circ} \mathrm{C}$. As previously described in Messer et al. (2017), filters were analysed on an elemental analyser (Thermo Finnigan MAT Conflo IV) coupled to an isotope ratio mass spectrometer (IRMS; Thermo Finnigan Delta XP; limit of detection $=15 \mu \mathrm{g} \mathrm{N}$ per filter) at the Research Corporation of the University of Hawaii.

\section{Biological $\mathbf{N}_{2}$ fixation incubations}

To measure rates of $\mathrm{N}_{2}$ fixation activity among planktonic diazotrophs, we performed stable isotope tracer addition experiments at each site with ${ }^{15} \mathrm{~N}$-labelled $\mathrm{N}_{2}$ gas. Acid-clean $(10 \% \mathrm{HCl})$ $4 \mathrm{~L}$ Nalgene incubation bottles were rinsed three times with seawater from the site prior to being filled to over-flowing via silicone tubing, then capped with rubber septa head-space free. ${ }^{15} \mathrm{~N}_{2}$ gas (3 ml, 98 atom\%, Sigma-Aldrich, Australia, lot SZ1670V, 2013 batch) was injected into each incubation bottle prior to inversion 100 times to disperse the gas bubble.

Samples for whole community $\mathrm{N}_{2}$ fixation (bulk seawater) and unicellular $\mathrm{N}_{2}$ fixation $(<10 \mu \mathrm{m}$ size fraction) were incubated in triplicate at in situ sea surface temperature using aquaria heaters and water circulation pumps attached to an outdoor $60 \mathrm{~L}$ plastic incubator, which was exposed to a natural diurnal light cycle at surface seawater intensity. ${ }^{15} \mathrm{~N}_{2}$ incubations were terminated via filtration after $24 \mathrm{~h}$, by directly filtering the entire contents onto a pre-combusted $\left(450^{\circ} \mathrm{C}\right.$ for $4 \mathrm{~h}$; packaged in aluminium foil) $\mathrm{GF} / \mathrm{F}$ grade $0.7 \mu \mathrm{m}$ filter (Whatman; whole community), or through a $10 \mu \mathrm{m}$ polycarbonate membrane filter (Isopore, Merck Millipore) onto a pre-combusted GF/F grade $0.7 \mu \mathrm{m}$ filter (Whatman; unicellular size fraction). Enriched filters were stored double contained in two snap-lock bags to prevent any possible cross-contamination and kept frozen at $20{ }^{\circ} \mathrm{C}$ prior to analysis.

Following methods described in Messer et al. (2017), ${ }^{15} \mathrm{~N}_{2}$ amended GF/F filters were dried (60 ${ }^{\circ} \mathrm{C}$ for $48 \mathrm{~h}$ ) separately to natural abundance samples to prevent cross-contamination. Total particulate $\mathrm{N}$ and $\mathrm{C}$ and isotopic composition were determined on an elemental analyser (Thermo Finnegan MAT Conflo IV) coupled to an IRMS (Thermo Finnegan Delta XP, limit of detection 
$238=15 \mu \mathrm{g} \mathrm{N}$ per filter) at the Research Corporation of the University of Hawaii. Assimilation rates 239 were calculated following Montoya et al. (1996). An atom\% enrichment equivalent to $75 \%$ of 240 the theoretical for a 24 hour incubation was used as the enrichment factor for volumetric rate 241 calculations to account for the incomplete dissolution of the ${ }^{15} \mathrm{~N}_{2}$ gas bubble (Großkopf et al., 242 2012; Mohr et al., 2010), following Messer et al. (2017).

243

\section{Collection, preservation, and extraction of microbial nucleic acids}

In order to concentrate microbial cells for nucleic acid extraction, amplicon sequencing, and quantitative PCR, triplicate $2 \mathrm{~L}$ samples were filtered onto $0.2 \mu \mathrm{m}$ membrane filters (Durapore, EMD Merck Millipore, Billerica, MA, USA). Filters were stored at $-20^{\circ} \mathrm{C}$ during the field sampling ( 2 weeks) and transported to the laboratory on dry ice before being stored at $-80{ }^{\circ} \mathrm{C}$ until extraction. The MoBio PowerWater DNA isolation kit (MoBio Laboratories, Carlsbad, CA, USA; now Qiagen) was used to extract microbial community DNA, following the manufacturer's guidelines including an additional incubation with solution PW1 (10 min at 60 $\left.{ }^{\circ} \mathrm{C}\right)$ prior to $10 \mathrm{~min}$ of bead beating, to ensure complete cell lysis.

\section{nifH amplicon sequencing and analyses}

To determine the diversity of diazotrophic bacterioplankton, a fragment of the $n i f H$ gene was amplified using a nested protocol and the degenerate primers nifH3 and nifH4, and nifH1 and nifH2 (Zani et al., 2000; Zehr and Turner, 2001), largely following methods previously described (Messer et al., 2015, 2016, 2017). The following PCR reaction conditions were used to amplify the nifH gene: $95^{\circ} \mathrm{C}(2 \mathrm{~min})$ followed by 30 cycles of $95^{\circ} \mathrm{C}(1 \mathrm{~min}), 48^{\circ} \mathrm{C}(1 \mathrm{~min})$ and $72{ }^{\circ} \mathrm{C}(1$ $\min )$ followed by $72^{\circ} \mathrm{C}(10 \mathrm{~min})$. Amplification was confirmed using gel electrophoresis, replicates were pooled, and the resultant fragment was sequenced using the 454 FLX Titanium pyrosequencing platform (Roche, Nutley, NJ, USA) at Molecular Research LP (Shallowater, TX, USA).

The Quantitative Insights Into Microbial Ecology (QIIME) (Caporaso et al., 2010) open source software was used to process nifH pyrosequencing reads. Briefly, sequences were de-multiplexed and the low-quality sequences were removed ( $q<25$ and $<200$ bp in length) using default parameters. Chimeric sequences were removed using USEARCH61 with default parameters against an unaligned version of a curated $n i f H$ reference database exported from Arb (downloaded from: http://wwwzehr.pmc.ucsc.edu/nifH_Database_Public/; Heller et al., 2014; Zehr et al., 2003). The remaining high-quality reads were clustered at $99 \%$ sequence identity using UCLUST, whereby sequences within $1 \%$ identity of the most abundant read were classified as operational taxonomic units (OTUs; Edgar, 2010). A representative sequence set was generated based on the most abundant sequence comprising an OTU. The PyNAST aligner tool (Caporaso et al., 2010a) was used with default parameters to BLAST and pairwise align representative nifH OTU sequences to those from the aligned version of the same curated $n i f H$ database used for chimera removal, providing putative taxonomy and "best hits" to primarily 
278 uncultured environmental sequences (Heller et al., 2014; Zehr et al., 2003). Any potential stop

279 codons and frameshifts in the $n i f H$ sequences were identified using the FrameBot tool from the

280 FunGene pipeline using default parameters (Fish et al., 2013). As part of this pipeline, taxonomy

281 was assigned to the closest representatives within the Ribosomal Database Project's nifH

282 database based on amino acid identity (AAI) and sequence alignment (Fish et al., 2013). Finally,

283 an OTU by sample matrix was generated, in which each sample was rarefied to the lowest

284 number of sequences per sample (3068) and singletons were removed prior to downstream

285 analyses.

286

287 Quantification of UCYN-A nifH genes

288 Based on our previous observations (Messer et al., 2015), we hypothesised that UCYN-A would

289 be the most important diazotrophic group within Spencer Gulf and the adjacent continental shelf

290 waters. In order to determine UCYN-A abundance, previously designed TaqMan qPCR probes

291 (Table S1) were utilised to quantify the UCYN-A1 (Langlois et al., 2008) and UCYN-A2

292 (Thompson et al., 2014) clades. qPCR standards were either cloned into the P-Gem T Easy

293 Vector (Promega, Sydney, NSW, Australia) following the manufacturer's guidelines (UCYN-

294 A2) as previously described (Messer et al., 2017), or synthesised into the PUC-57 Amp

295 (Genewiz) vector (UCYN-A1). The nifH gene inserts were then amplified from the plasmid

296 DNA using plasmid specific PCR primers targeting the M13 binding site of the vector. A band of

297 the correct size was purified from an electrophoresis gel using the Isolate II Gel/PCR Purification

298 kit (Bioline, Eveleigh, NSW, Australia). DNA was then quantified using a Qubit Fluorometer

299 and serially diluted to generate a standard curve incorporating $10^{7}$ to $10^{1}$ nifH copies.

300

301

302

qPCR reactions were performed as previously described in Messer et al. (2017). Specifically,

303 template DNA was diluted 1:5 using nucleic-acid-free $\mathrm{H}_{2} \mathrm{O}$ to prevent inhibition and $5 \mu 1$ of the template dilution was subsequently used in the qPCR assay. Each qPCR reaction included 200 $\mathrm{nM}$ of forward and reverse primer, $100 \mathrm{nM}$ of TaqMan probe, 2x TaqMan Master Mix II, and 3 $\mu 1$ of nucleic-acid-free $\mathrm{H}_{2} \mathrm{O}$. Samples were analysed in triplicate, with additional triplicate technical replicates and triplicate no template negative controls $\left(5 \mu 1\right.$ nucleic-acid-free $\left.\mathrm{H}_{2} \mathrm{O}\right)$, alongside the relevant standards (also analysed in triplicate). Reaction conditions were optimised for each primer and probe set using a combination of temperature, annealing time, and extension time gradients on a StepOnePlus ${ }^{\mathrm{TM}}$ Real-Time PCR machine (software v2.3; Applied Biosystems, Thermo Fisher Scientific, Scoresby, Victoria, Australia). The final optimal reaction conditions were identified to be: $50^{\circ} \mathrm{C}(5 \mathrm{~min}), 95^{\circ} \mathrm{C}(10 \mathrm{~min})$ and 40 cycles of $95^{\circ} \mathrm{C}(15 \mathrm{sec})$ and $64{ }^{\circ} \mathrm{C}(60 \mathrm{sec})$ for UCYN-A2; and $95{ }^{\circ} \mathrm{C}(10 \mathrm{~min})$ followed by 40 cycles of $95{ }^{\circ} \mathrm{C}(15 \mathrm{sec})$, $55^{\circ} \mathrm{C}(15 \mathrm{sec})$ and $72{ }^{\circ} \mathrm{C}(60 \mathrm{sec})$ for UCYN-A1. Linear regression analyses of quantification cycle $(\mathrm{Cq})$ versus $\log 10$ nifH gene copies demonstrated that the UCYN-A2 assay had a mean $\mathrm{R}^{2}$ of 0.999 and an efficiency between $99.2-99.9 \%$ and the UCYN-A1 assay had a mean $\mathrm{R}^{2}$ of each assay was identified to be equivalent to $\sim 1-10$ nifH copies per reaction. 


\section{Statistical analyses}

320

321

Prior to testing for significant differences between "season" and "site", environmental data, $\mathrm{N}_{2}$ fixation rates, and qPCR data were checked for normality and homogeneity of variance using the Shapiro-Wilk and Brown-Forsythe tests respectively (SPSS, IMB Statistics 24). Data meeting these criteria were tested for significance using a one-way ANOVA, while a Kruskal Wallis ANOVA on ranks was used for data that failed to meet the stipulations of normality (SPSS, IMB Statistics 24). Pearson correlation coefficients and significance values were calculated (SPSS,

327

328

329

330

331

332

333

334

335

336

337

338

339

340

341

342

343

344

345

346

347

348

349

350

351

352

353

354

355

356

357 IMB Statistics 24) between biological and environmental variable pairs across the entire dataset, and independently for samples collected in Austral autumn or summer.

Statistical analyses of diazotroph community dissimilarity were performed using the PRIMER 7 + PERMANOVA software. The final OTU by sample matrix was square-root transformed and a Bray Curtis resemblance matrix was generated. Significant differences between nifH amplicon sequencing profiles were explored using the non-parametric Analysis of Similarity (ANOSIM) test, using either "season" or "site" as a factor, while the contribution of each OTU to the observed dissimilarity between sampling sites was determined using Similarity Percentage analysis (SIMPER). In addition, a distance-based linear model (DistLM) was generated from the Bray-Curtis resemblance matrix, using the corresponding site-specific environmental metadata as predictor variables. Relationships between the environmental predictor variables and diazotroph community composition were also investigated using the BEST, biota and environment (BIOENV) test, using Spearman rank correlation.

The multivariate relationships between individual diazotroph OTUs, environmental metadata, and $\mathrm{N}_{2}$ fixation rates were explored using a negative binomial many-generalised linear model (Wang et al., 2012). The model was performed using the mvabund (v.4.1.3) package (Wang et al., 2012) in R (v4.0.2) and R studio (v1.3.959) (R Core Team, 2013). The nifH OTU by sample matrix was input as count data and converted to an mvabund object prior to model creation using the 'manyglm' function. The analysis of deviance table was generated using the 'anova' function with 'p.uni = adjusted' selected to correct for the effect of multiple testing.

\section{Results}

\section{Environmental characteristics of Spencer Gulf and shelf waters}

Consistent with the inverse estuarine nature and seasonal variability of Spencer Gulf, patterns in sea surface temperature (SST) and salinity exhibited a clear transition from cooler oceanic conditions in southern shelf waters, to warmer and hypersaline conditions in the northern region of the Gulf (Figure 1; Table 1). Across this gradient, SST ranged from $18{ }^{\circ} \mathrm{C}$ to $\sim 23{ }^{\circ} \mathrm{C}$, while salinity increased from 36 at the mouth to $\geq 40$ at the northern site (Table 1). During the Austral autumn, SST was typically lower than SST observed during the summer (Table 1), with mean 
358

359

360

361

362

363

364

365

366

367

368

369

370

371

372

373

374

375

376

377

378

379

380

381

382

383

384

385

386

387

388

389

390

391

392

393

394

395

396

397

temperature ( \pm standard deviation) across the five sites, $18.9 \pm 0.8^{\circ} \mathrm{C}$ relative to $21.0 \pm 1.8^{\circ} \mathrm{C}$, respectively. In contrast, the salinity profile of Spencer Gulf was highly similar during both the Austral autumn and summer across the five sampling sites, with means for each season $( \pm$ standard deviation) of $37.3 \pm 1.65$ and $37.1 \pm 1.81$, respectively.

Concentrations of dissolved inorganic nutrients were relatively stable between the southern shelf and northern Spencer Gulf waters. Indeed, $\mathrm{NO}_{3} / \mathrm{NO}_{2}$ concentrations were always $<0.05 \mu \mathrm{M}$, and $\mathrm{PO}_{4}$ concentrations were generally low, ranging from 0.01 (i.e., limit of detection) to $0.08 \mu \mathrm{M}$ across the five sampling locations (Table 1). Mean ( \pm standard deviation) $\mathrm{NO}_{3} / \mathrm{NO}_{2}$ and $\mathrm{PO}_{4}$ concentrations were similar between the two sampling periods, at $0.02 \pm 0.01$ and $0.03 \pm 0.02$ $\mu \mathrm{M}$ during Austral autumn, and $0.03 \pm 0.01$ and $0.04 \pm 0.03 \mu \mathrm{M}$ during Austral summer, respectively. Conversely, concentrations of $\mathrm{SiO}_{4}$ showed a sharp increase from the southern shelf to northern Gulf waters, ranging from 0.22 up to $1.10 \mu \mathrm{M}$ (Table 1). While mean $\mathrm{SiO}_{4}$ concentrations were typically elevated during Austral autumn compared to summer, at $0.49 \pm$ 0.36 and $0.38 \pm 0.14 \mu \mathrm{M}$, respectively.

\section{Biological $\mathbf{N}_{\mathbf{2}}$ fixation rates in temperate southern Australia}

Measurable rates of $\mathrm{N}_{2}$ fixation occurred at all sites during both the Austral autumn and summer, but rates were highly heterogeneous ranging from $2 \mathrm{nmol} \mathrm{L}^{-1} \mathrm{~d}^{-1}$ to $64 \mathrm{nmol} \mathrm{L}^{-1} \mathrm{~d}^{-1}$ (Figure 2). Across the entire dataset, no significant differences were observed between whole community (WC) and unicellular size fraction (USF) $\mathrm{N}_{2}$ fixation rates (Kruskal-Wallis test, $\mathrm{H}=0.32$, d.f. $=$ $1, \mathrm{n}=30, \mathrm{P}=0.574$ ), indicating that the unicellular size fraction contributed the majority of the observed $\mathrm{N}_{2}$ fixation activity. Overall, no significant differences in $\mathrm{N}_{2}$ fixation rates were observed between incubations conducted during Austral autumn compared to summer (KruskalWallis test, $\mathrm{H}=1.397$ and 1.931, d.f. $=1, \mathrm{P}=0.237$ and 0.165 , for $\mathrm{WC}$ and USF respectively; $\mathrm{n}$ $=15$ per season). During both Austral autumn and summer, $\mathrm{WC}$ and $\mathrm{USF}_{2}$ fixation rates were highly correlated, with Pearson correlation coefficients (r) of 0.85 and 0.76 respectively, further supporting the proposition that the unicellular size fraction contributed the majority of the observed $\mathrm{N}_{2}$ fixation activity

When grouped by "site" as opposed to "season", $\mathrm{N}_{2}$ fixation rates exhibited significant spatial heterogeneity (One-way ANOVA, $\mathrm{P} \leq 0.001, \mathrm{~F}=37.38$, d.f. $=4, \mathrm{n}=6$ per site). The lowest rates of $\mathrm{N}_{2}$ fixation during both the Austral autumn and summer occurred in the southern shelf waters, with maximum rates at this site reaching only $8 \pm 2 \mathrm{nmol} \mathrm{L}^{-1} \mathrm{~d}^{-1}$ (mean \pm standard deviation; Figure 2). In contrast, $\mathrm{N}_{2}$ fixation rates peaked in the waters at the mouth of Spencer Gulf, where they reached $64 \pm 3$ and $40 \pm 19 \mathrm{nmol} \mathrm{L}^{-1} \mathrm{~d}^{-1}$, in Austral autumn and summer respectively (Figure 2). Relative to rates observed at the mouth of Spencer Gulf, $\mathrm{N}_{2}$ fixation rates decreased at the southern and mid-western sites of the gulf during both autumn and summer (Figure 2). $\mathrm{N}_{2}$ fixation rates then showed a notable increase at the northern-gulf site, reaching $29 \pm 4 \mathrm{nmol} \mathrm{L}^{-1}$ $\mathrm{d}^{-1}$ during Austral autumn, and $14 \pm 10 \mathrm{nmol} \mathrm{L}^{-1} \mathrm{~d}^{-1}$ during Austral summer (Figure 2). 
$\mathrm{N}_{2}$ fixation rates were significantly correlated with low concentrations of $\mathrm{NO}_{3} / \mathrm{NO}_{2}$ (Pearson's $\mathrm{r}$ :

400

401

402

403

404

405

406

407

408

409

410

411

412

413

414

415

416

417

418

419

420

421

422

423

424

425

426

427

428

429

430

431

432

433

434

435

436

437 $-0.53 ; \mathrm{P}=0.002, \mathrm{n}=30, \mathrm{USF})$. This relationship was maintained when considering only Austral summer samples ( $\mathrm{r}:-0.64 ; \mathrm{P}=0.01 ; \mathrm{n}=15$, USF), but not when only considering those collected during Austral autumn. In contrast, during the Austral autumn $\mathrm{N}_{2}$ fixation rates were positively correlated to $\mathrm{PO}_{4}$ concentrations ( $\mathrm{r}: 0.73 ; \mathrm{P}=0.002 ; \mathrm{n}=15$, WC). No significant relationships were observed between $\mathrm{N}_{2}$ fixation and SST or salinity, despite clear spatial gradients in these environmental parameters (Table 1).

\section{Diversity and composition of $\boldsymbol{n i f H}$ containing bacterioplankton}

After rarefaction to 3068 sequences per sample and the removal of singletons, between 159 and 332 nifH OTUs were detected at each sampling site. The diversity of nifH containing bacterioplankton increased along the latitudinal gradient of Spencer Gulf, whereby Shannon's Diversity $\left(\mathrm{H}^{\prime}\right)$ was lowest in the southern shelf waters, where $\mathrm{H}^{\prime}=1.95$ and 2.86 and peaked at the mid-western edge of Spencer Gulf, where H' $=4.97$ and 4.37, during Austral autumn and summer respectively (Table S2). Despite the site-specific differences in diazotroph diversity, mean H' across the Gulf was approximately equal for both sampling seasons, whereby $\mathrm{H}^{\prime}=3.67$ during austral autumn, and $\mathrm{H}^{\prime}=3.58$ during austral summer.

Phylogenetic analyses of $n i f H$ sequences demonstrated that the most abundant OTUs ( $\mathrm{n}=25$ ), equivalent to $\sim 53 \%$ of total sequences and between 15 and $82 \%$ of sequences for any given sample, comprised a mixture of Cluster 1 and Cluster 3 diazotrophs at $\geq 83 \%$ amino acid identity (AAI; Table S3). A Bray-Curtis resemblance matrix of rarefied nifH sequence data was used to compare diazotroph community composition within and between the southern shelf waters and Spencer Gulf sampling locations, revealing significant spatial variability in diazotroph assemblage structure (ANOSIM, R: 0.59, $\mathrm{P}=0.005$ ). SIMPER analysis revealed 99.7 $\%$ and $100 \%$ community dissimilarity between northern Gulf diazotroph assemblages and those in the shelf waters and at the mouth of the Gulf, respectively. Diazotroph assemblages in the shelf waters and mouth were dominated by five OTUs identified to be the UCYN-A1 open ocean ecotype (OTU51120, OTU3535, OTU45147, OTU7980, and OTU1115; Fig. S1), which collectively represented $75 \%$ and $56 \%$ of sequences at the shelf during Austral autumn and summer respectively (Figure 3). Similarly, these OTUs comprised $54 \%$ and $58 \%$ of sequences at the mouth during Austral autumn and summer (Figure 3). Correspondingly, diazotroph communities in the southern shelf waters and at the mouth of the gulf shared the greatest similarity in composition, with SIMPER analysis revealing only $63.4 \%$ dissimilarity between these populations. The dissimilarity between the shelf waters and the mouth was largely driven by the coastal and open ocean ecotypes UCYN-A2 and UCYN-A4 (OTU9097 and OTU67260, respectively), which were collectively present at higher relative abundances at the mouth (Figure 3). 
438 Spencer Gulf communities showed a decline in the abundance of UCYN-A OTUs, and a greater 439 proportion of sequences associated with non-cyanobacterial diazotrophs, along with a small 440 proportion of OTUs closely related to filamentous cyanobacteria such as Trichodesmium 441 erythraeum (Figure 3; Table S3). The average relative abundance of two UCYN-A1 open ocean 442 group OTUs, (OTU51120 and OTU3535), were identified by SIMPER analysis as the main 443 drivers of community dissimilarity between the shelf waters, Spencer Gulf mouth, and northern

444

445

446

447

448

449

450

451

452

453

454

455

456

457

458

459

460

461

462

463

464

465

466

467

468

469

470

471

472

473

474

475

476

477 gulf diazotroph assemblages. At the southern gulf site, a transitional community was observed, which comprised UCYN-A1 and UCYN-A2 (12 - 44\% of sequences), Pseudomonas stutzeri (7 $\%)$, Desulfovibrio aespoeensis (8 - $12 \%)$, Coraliomargarita akajimensis (7\%), and Desulfonatronospira thiodismutans (7\%). In contrast, at the northern site the community was primarily comprised of OTUs related to Desulfovibrio aespoeensis (10 - 28\%), Pseudomonas stutzeri (11\%), and Verrucomicrobiae (11\%; Figure 3). SIMPER analysis identified the Desulfovibrio aespoeensis OTU (OTU41624; 96 \% AAI similarity) as also being responsible for the between-site discrimination of the diazotroph community, with this OTU absent from assemblages detected in the southern waters. Interestingly, only a small proportion of the most abundant 25 OTUs were represented at the mid-Spencer Gulf site (15 - $38 \%$ ) and northernSpencer Gulf site (32 - $36 \%$ ) especially during the Austral autumn. Instead, overall low abundance OTUs, which were typically unique to these sites (i.e., OTUs representing $<0.5 \%$ of total sequences), were responsible for the high alpha diversity associated with these sites.

Across the dataset, several variables were identified as having a significant effect on the relative abundance and composition of diazotrophic bacterioplankton within Spencer Gulf and the adjacent shelf waters. These included $\mathrm{NO}_{3} / \mathrm{NO}_{2}(\mathrm{P}=0.002), \mathrm{N}_{2}$ fixation by the unicellular size fraction $(\mathrm{P}=0.007)$ and the whole community $(\mathrm{P}=0.016)$, salinity $(\mathrm{P}=0.017)$, temperature $(\mathrm{P}=$ 0.037), particulate nitrogen ( $\mathrm{PN} ; \mathrm{P}=0.039)$, and $\mathrm{PO}_{4}(\mathrm{P}=0.048$; Many GLM, Table S4). Only three of these predictors displayed significant relationships (adjusted P-value $<0.1$ ) with individual OTUs, including PN (1 OTU), $\mathrm{N}_{2}$ fixation by the unicellular size fraction (14 OTUs), and salinity (4 OTUs; Table S4).

Approximately $33 \%$ of the spatial variation in diazotroph community dissimilarity could be explained by ambient salinity and $\mathrm{SiO}_{4}$ concentrations (DistLM R $\mathrm{R}^{2}$ : 0.33 ; salinity $\mathrm{F}=2.24, \mathrm{P}=$ $0.001 ; \mathrm{SiO}_{4} \mathrm{~F}=1.56, \mathrm{P}=0.028 ; \mathrm{n}=10$ ). The importance of salinity and $\mathrm{SiO}_{4}$ in structuring the diazotroph community was further confirmed by BEST/BIOENV analyses, resulting in a significant $(\mathrm{P}=0.01, \mathrm{n}=10)$ coefficient, $\mathrm{Rho}=0.67$, using Spearman's Rank correlation. The sequential addition of the environmental parameters, $\mathrm{PN}, \mathrm{NO}_{3} / \mathrm{NO}_{2}$, and $\mathrm{PO}_{4}$, reduced the strength of the correlation to $0.56,0.52$, and 0.49 , respectively. In contrast to the observed spatial heterogeneity in diazotroph assemblage structure, no significant differences in diazotroph community dissimilarity were observed between the Austral autumn and summer sampling times (ANOSIM, R: -0.12, $\mathrm{P}=0.80$ ). 
478 Abundance of UCYN-A1 and UCYN-A2 nifH genes

479 qPCR derived abundances of UCYN-A1 and UCYN-A2 nifH genes demonstrated higher

480 abundances of these organisms in shelf waters and at the more southern sites of Spencer Gulf

481 (Figure 4). Specifically, the maximum mean abundance of UCYN-A1 occurred in the southern

482 shelf waters during Austral summer, whereby $5.4 \pm 4.7 \times 10^{4}$ nifH copies L ${ }^{-1}$ were detected

483 (Figure 4). Similarly, UCYN-A2 also reached maximum abundance in the shelf waters during

484 Austral summer, with mean nifH copies $1.9 \pm 1.4 \times 10^{4} \mathrm{~L}^{-1}$ (Figure 4).

485

486

487

Across all sampling locations, UCYN-A1 was significantly more abundant during the Austral

488 summer compared to autumn (Mann Whitney test, U: 69, P < 0.05). While UCYN-A2 abundances did not differ significantly between the Austral autumn and summer sampling. Across the entire dataset, UCYN-A1 abundance was positively correlated with concentrations of $\mathrm{PO}_{4}(\mathrm{r}: 0.39 ; \mathrm{P}=0.03, \mathrm{n}=30)$. In contrast, overall UCYN-A2 abundance was not significantly correlated with any of the measured environmental parameters. However, when analysed by "season", UCYN-A2 abundance was negatively correlated to SST during both Austral autumn and summer ( $\mathrm{n}=15$ per season; $\mathrm{r}$ : -0.55 and $\mathrm{r}$ : $-0.53, \mathrm{P}=0.03$ and 0.04 , respectively). In addition, during Austral autumn UCYN-A2 abundance was negatively correlated to $\mathrm{PO}_{4}$ concentrations ( $\mathrm{r}:-0.53 ; \mathrm{P}=0.04 ; \mathrm{n}=15)$. Despite the potential importance of salinity in structuring the overall diazotroph community, no significant relationships were observed

498

499

500 between UCYN-A qPCR derived abundances and salinity.

501

\section{Discussion}

Increasing evidence suggests that temperate coastal waters may be overlooked hotspots of $\mathrm{N}_{2}$

502 fixation activity (Mulholland et al., 2012, 2019; Tang et al., 2019b). Determining the distribution

503 and activity of diazotrophs, and the environmental processes that influence them within coastal

504 zones is therefore important to further our understanding of $\mathrm{N}$ availability across diverse marine environments. Compared to previous studies in temperate and tropical estuarine environments, where maximum $\mathrm{N}_{2}$ fixation rates of $30-85 \mathrm{nmol} \mathrm{L}^{-1} \mathrm{~d}^{-1}$ have been observed (Ahmed et al., 2019; Bentzon-Tilia et al., 2015b; Bhavya et al., 2016), here we report relatively high rates of $\mathrm{N}_{2}$ fixation in temperate coastal waters of southern Australia within the inverse estuary Spencer

509 Gulf. We show that $\mathrm{N}_{2}$ fixation rates, diazotroph diversity, and community structure, can vary considerably across relatively small spatial scales, however the dynamics of $\mathrm{N}_{2}$ fixation were relatively stable across two contrasting seasons. Our findings suggest that $\mathrm{N}_{2}$ fixation, possibly

512 mediated by UCYN-A and non-cyanobacterial diazotrophs, may provide an important source of 513 fixed $\mathrm{N}$ to support primary production within the oligotrophic, temperate coastal waters of 514 southern Australia.

515

\section{$\mathrm{N}_{2}$ fixation in temperate coastal environments}


517 Recent efforts to determine the importance of $\mathrm{N}_{2}$ fixation as a source of new $\mathrm{N}$ within temperate 518 coastal waters have revealed $\mathrm{N}_{2}$ fixation activity in these regions is similar to, and at times higher 519 than, rates reported for tropical and subtropical open ocean environments (Mulholland et al., 520 2019; Tang et al., 2019b). For example, maximum $\mathrm{N}_{2}$ fixation rates of 65, 130, and $100 \mathrm{nmol} \mathrm{L}^{-1}$ $521 \mathrm{~d}^{-1}$ have recently been observed in coastal waters of the north-eastern, mid-, and western Atlantic 522 Ocean respectively (Fonseca-Batista et al., 2019; Mulholland et al., 2019; Tang et al., 2019b). In 523 environments representing the traditional niche of $\mathrm{N}_{2}$ fixation, such as the North Pacific

524 Subtropical Gyre (NPSG) and the Eastern South Pacific (ESP), maximum $\mathrm{N}_{2}$ fixation rates have 525 been reported to be considerably lower at $\leq 20 \mathrm{nmol} \mathrm{L}^{-1} \mathrm{~d}^{-1}$ (Böttjer et al., 2017; Gradoville et al., 526 2017; Shiozaki et al., 2017).

527

528

529

530

531

532

533

534

In the temperate coastal waters of southern Australia, we observed relatively high rates of $\mathrm{N}_{2}$ fixation, with a maximum $\mathrm{N}_{2}$ fixation rate of $64 \mathrm{nmol} \mathrm{L}^{-1} \mathrm{~d}^{-1}$. This observation is similar in magnitude to the high $\mathrm{N}_{2}$ fixation rates reported for the tropical oligotrophic seas of northern Australia (Bonnet et al., 2015; Messer et al., 2016), and is almost double maximum $\mathrm{N}_{2}$ fixation rates previously reported for tropical estuarine systems (31 - $34 \mathrm{nmol} \mathrm{L} \mathrm{L}^{-1} \mathrm{~d}^{-1}$; Ahmed et al., 2019; Bhavya et al., 2016). The lowest rates of $\mathrm{N}_{2}$ fixation $\left(2 \mathrm{nmol} \mathrm{L}^{-1} \mathrm{~d}^{-1}\right)$ occurred in the continental shelf waters. This finding is comparable to observations from other continental shelf ecosystems where $\mathrm{N}_{2}$ fixation rates are typically lower that those observed in sites closer to the coast (Mulholland et al., 2012; Shiozaki et al., 2015a; Singh et al., 2019). Intermediate rates of $\mathrm{N}_{2}$ fixation (10 - $\left.45 \mathrm{nmol} \mathrm{L}^{-1} \mathrm{~d}^{-1}\right)$ were measured within Spencer Gulf, and these rates are placed within the upper end of those previously reported for other temperate coastal, and tropical estuarine waters (Ahmed et al., 2019; Bentzon-Tilia et al., 2015b; Bhavya et al., 2016; Mulholland et al., 2012; Rees et al., 2009; Shiozaki et al., 2015a). Importantly, our findings demonstrate that $\mathrm{N}_{2}$ fixation in the temperate waters of southern Australia are similar to, and can 543

544 While $\mathrm{N}_{2}$ fixation rates demonstrated clear spatial patterns in their magnitude between southern shelf and Spencer Gulf waters, we observed relatively consistent $\mathrm{N}_{2}$ fixation rates across

546 opposing seasons. This is in contrast to previous seasonal observations of $\mathrm{N}_{2}$ fixation from 547 distinct marine environments, where $\mathrm{N}_{2}$ fixation rates are typically higher during spring/summer 548 than autumn/winter and are accompanied by shifts in the abundance of different diazotrophic 549 taxa (Bentzon-Tilia et al., 2015b; Böttjer et al., 2017; Fernandez et al., 2015; Mulholland et al., 550 2019). We hypothesised that seasonal differences in $\mathrm{N}_{2}$ fixation rates would occur within 551 Spencer Gulf and shelf waters due to the known seasonality in physico-chemical characteristics, 552 such as temperature, salinity, and dissolved nutrients, which ultimately influence the distribution 553 and activity of marine diazotrophic microorganisms (Monteiro et al., 2011; Moore et al., 2013; 554 Ward et al., 2013). However, while limited in replication, we observed relatively stable site555 specific physico-chemical conditions between the two contrasting seasons, and no significant 556 differences in the composition of the underlying diazotrophic community. While limited in scope 
557 to two time-points, our observations suggest that relatively high $\mathrm{N}_{2}$ fixation rates can be

558

559

560

561

562

563

564

565

566

567

568

569

570

571

572

573

574

575

576

577

578

579

580

581

582

583

584

585

586

587

588

589

590

591

592

593

594

595

596

maintained within Spencer Gulf while favourable conditions prevail. In future, increased sampling resolution is required to define the seasonal dynamics of $\mathrm{N}_{2}$ fixation within the temperate coastal waters of southern Australia.

\section{Regional significance of biological $\mathbf{N}_{\mathbf{2}}$ fixation}

Our previous research indicated that the pelagic microbial community of Spencer Gulf includes a diverse array of diazotrophic clades (Messer et al., 2015). However, the presence of diazotrophic groups cannot solely be used as evidence for the importance of pelagic $\mathrm{N}_{2}$ fixation, as the physiological process is tightly regulated (Paerl et al., 1987). To the best of our knowledge, our observations of $\mathrm{N}_{2}$ fixation within the pelagic realm of Spencer Gulf represent the first $\mathrm{N}_{2}$ fixation measurements from a temperate inverse estuary. Our $\mathrm{N}_{2}$ fixation rate measurements support our hypothesis that pelagic $\mathrm{N}_{2}$ fixation may provide a supply of fixed $\mathrm{N}$ within Spencer Gulf and the southern shelf waters, at considerably high rates relative to tropical and subtropical open ocean environments. In an earlier study, Middleton et al. (2013) estimated the influx of bioavailable $\mathrm{N}$ (in the form of $\mathrm{NO}_{3}$ and $\mathrm{NH}_{4}$ ) within Spencer Gulf to be 16.9 kilotonnes $\mathrm{yr}^{-1}$, including anthropogenic $\mathrm{N}$ sources and mixing of upwelled nutrients from continental shelf waters. This estimate did not include biological $\mathrm{N}_{2}$ fixation as a source of $\mathrm{N}$, using their estimate of the volume of Spencer Gulf $\left(4.58 \times 10^{14} \mathrm{~L}\right)$, the $\mathrm{N}_{2}$ fixation rates measured herein could theoretically contribute an additional 23-149 kilotonnes $\mathrm{N} \mathrm{yr}^{-1}$, albeit assuming consistent daily $\mathrm{N}_{2}$ fixation rates for a given site. Indeed, an accurate $\mathrm{N}$ budget would require extensive additional $\mathrm{N}_{2}$ fixation rates, with the appropriate modifications to the bubble method used to measure $\mathrm{N}_{2}$ fixation (White et al., 2020). Nevertheless, based on our estimates, we propose that the process of biological $\mathrm{N}_{2}$ fixation could be one mechanism by which productivity is maintained throughout the region.

It must be noted that the $\mathrm{N}_{2}$ fixation rates presented herein have been corrected to allow for the incomplete dissolution of the ${ }^{15} \mathrm{~N}_{2}$ gas bubble at $75 \%$ of the theoretical for a 24 hour incubation (Großkopf et al., 2012; Mohr et al., 2010). However, recent methodological comparisons suggest no "global factor" exists for rate corrections to the bubble method (Wannicke et al., 2018; White et al., 2020). Despite the known caveats of the bubble method, this approach was used in the present study due to the predicted highly dissimilar environmental conditions at each site, which would be very difficult to replicate with pre-prepared ${ }^{15} \mathrm{~N}_{2}$ saturated artificial seawater (Wilson et al., 2012). In particular, the observed gradient in ambient temperature and salinity, which determines gas solubility and is accounted for in the rate calculations based on our observations at each site, would be difficult to anticipate ahead of sample collection. We also note that contamination of Sigma-Aldrich commercial ${ }^{15} \mathrm{~N}_{2}$ gas stocks was reported after our initial study (Dabundo et al., 2014). Although we cannot explicitly rule out contamination in the batch of ${ }^{15} \mathrm{~N}_{2}$ that we used, assuming the mean values for Sigma Aldrich lot SZ1670V reported in Table 1 of Dabundo et al. (2014) are consistent across batches, we estimate that potential contamination

Peer) reviewing PDF | (2020:05:48794:2:0:NEW 17 Dec 2020) 
597 from ${ }^{15} \mathrm{NO}_{3},{ }^{15} \mathrm{NH}_{4}$, and ${ }^{15} \mathrm{~N}_{2} \mathrm{O}$, would represent an extremely small proportion of additional ${ }^{15} \mathrm{~N}$ 598 in our incubations, equivalent to a total of $3.2 \times 10^{-7}$ moles. In our experiments, the relative 599 concentration of ${ }^{15} \mathrm{~N}$ gas added was $2.7 \times 10^{-4}$ moles. Including this estimate of additional ${ }^{15} \mathrm{~N}$ in 600 our trace additions, any potential contamination would inflate our $\mathrm{N}_{2}$ fixation rates by between $6010.001-0.079 \mathrm{nmol} \mathrm{L}^{-1} \mathrm{~d}^{-1}$, which is within the lower end of the inferred $\mathrm{N}_{2}$ fixation rates 602 resulting from ${ }^{15} \mathrm{NH}_{4}$ contamination for $4.5 \mathrm{~L}$ incubations, presented in Table 2 of Dabundo et al. 603 (2014). Moreover, this estimate is within our calculated standard error of mean $\mathrm{N}_{2}$ fixation rates 604 across triplicate samples (equivalent to $0.05-10.77 \mathrm{nmol} \mathrm{L}^{-1} \mathrm{~d}^{-1}$ ). Therefore, any potential 605 contamination would have a negligible effect on the ultimate $\mathrm{N}_{2}$ fixation rates reported herein. In 606 future work, the modified bubble method should be employed, including additional determination of ${ }^{15} \mathrm{~N}_{2}$ atom\% enrichment of individual incubation bottles and ${ }^{15} \mathrm{~N}_{2}$ gas purity, as

608 recently suggested by the scientific community (Jayakumar et al., 2017; Klawonn et al., 2015;

609 White et al., 2020).

610

611

612

\section{Identifying the key players in coastal $\mathrm{N}_{2}$ fixation}

613 fixation activity is important for deciphering the potential impact of newly fixed $\mathrm{N}$ to a given 614 region (Mulholland, 2007; Zehr and Kudela, 2011). For instance, throughout tropical and 615 subtropical open ocean environments, $\mathrm{N}_{2}$ fixation by autotrophic diazotrophs such as 616 Trichodesmium sp. will contribute directly to local primary production and may also release

617 recently fixed $\mathrm{N}_{2}$ into the water column to support the growth of non-diazotrophic organisms 618 (Berthelot et al., 2015; Caffin et al., 2018; Garcia et al., 2007; Glibert and Bronk, 1994;

619 Mulholland et al., 2004). On the other hand, symbiotic diazotrophs such as the heterocystous 620 cyanobacterium Richelia, which is typically associated with "tropical" phytoplankton species, 621 transfer fixed $\mathrm{N}_{2}$ directly to their eukaryotic phytoplankton host (Foster et al., 2011), and 622 therefore contribute to new production and carbon sequestration in regions where they are 623 abundant, such as the NPSG (Karl et al., 2012). While the contribution of newly fixed N by non624 cyanobacterial diazotrophs is not yet clear (Turk-Kubo et al., 2014), their combined high 625 abundances and widespread transcriptional activity in areas of high $\mathrm{N}_{2}$ fixation rates (Bird and 626 Wyman, 2013; Chen et al., 2018; Langlois et al., 2015; Moisander et al., 2014), indicate that they 627 could make an important contribution to support primary production in both open ocean and 628 coastal environments.

629

630 The diversity of diazotrophic organisms detected in the present study indicates that $\mathrm{N}_{2}$ fixation 631

632 activity may directly and indirectly support primary production within Spencer Gulf. Within the

633 diverse diazotrophic communities detected, Cluster 1B UCYN-A, and Cluster $1 \mathrm{G}$ and Cluster 3 Proteobacteria, dominated diazotroph community profiles. Specifically, we observed high relative abundances of sequences closely related ( $\geq 96 \% \mathrm{AAI})$ to the symbiotic UCYN-A, in addition to the presumed free-living Pseudomonas stutzeri and Desulfovibrio aespoeensis, as well as lower relative abundances of the large filamentous tropical cyanobacterium 
637 Trichodesmium erythraeum. To date, UCYN-A and gammaproteobacterial diazotrophs (related 638 to Pseudomonas stutzeri), have consistently been observed within temperate coastal diazotroph 639 communities (Bentzon-Tilia et al., 2015b; Mulholland et al., 2019; Needoba et al., 2007;

640 Shiozaki et al., 2015b), but they are also key components of subtropical and tropical assemblages 641 (Bonnet et al., 2015; Langlois et al., 2015; Moisander et al., 2014). Our observations provide 642 further support for the global significance of these groups, although it must be noted that the 643 Pseudomonas stutzeri OTUs did not cluster with known sequences from the globally distributed 644 Gamma A clade.

645

646 While the presence of Trichodesmium erythraeum was somewhat unexpected due to its tropical

647

648

649

650

651

652

653

654

655

656

657

658

659

660

661

662

663

664

665

666

667

668

669

670

671

672

673

674

675

676 and subtropical distribution (Capone et al., 2005), sequences related to Trichodesmium sp. have previously been observed at temperate latitudes of the Atlantic and Pacific Oceans (Mulholland et al., 2019; Rivero-Calle et al., 2016; Shiozaki et al., 2015a), and their presence has also been reported in south Australian waters based on microscopic observations (Paxinos, 2007). We did not determine the specific activity of Trichodesmium $s p$. within our samples, however, it comprised up to $17 \%$ of the diazotroph community at the mid-Gulf site during Austral summer. Owing to its presence and potential importance for both local primary production and $\mathrm{N}$ availability, further investigation into the significance of Trichodesmium $s p$. within temperate coastal waters is required.

Consistent with our previous observations of UCYN-A diversity and distribution within Spencer Gulf (Messer et al., 2015), we observed differences in the abundances of the open-ocean UCYNA1 and the coastal UCYN-A2 within and between the southern shelf waters. The emerging sublineage UCYN-A4 (Farnelid et al., 2016) was also detected in our amplicon sequencing profiles during Austral summer. Due to the similarity between this OTU and the UCYN-A2 qPCR assay of Thompson et al. (2014), we cannot rule out that our qPCR derived abundances do not contain a mixture of the UCYN-A2 and UCYN-A4 sub-lineages (Farnelid et al., 2016). Since UCYN$\mathrm{A} 1$, and to a lesser extent UCYN-A2 (possibly A2/A3/A4 sub-lineages), have recently been shown to be highly abundant $\left(\leq 10^{6}\right.$ nifH copies $\left.\mathrm{L}^{-1}\right)$ and reasonably active, fixing $\mathrm{N}_{2}$ at rates of 6 nmol L-1 $\mathrm{d}^{-1}$ in the cold surface waters of the Western Arctic Ocean (Harding et al., 2018), UCYN-A are highly likely to be important mediators of $\mathrm{N}_{2}$ fixation within Spencer Gulf and more broadly across temperate and coastal marine environments.

\section{What environmental factors influence $\mathrm{N}_{2}$ fixation in temperate southern Australian waters?}

Across the global ocean, SST and subsurface minimum dissolved oxygen concentrations have been identified as the major environmental variables influencing pelagic $\mathrm{N}_{2}$ fixation rates (Luo et al., 2014; Tang et al., 2019a). In addition, the availability of dissolved iron, phosphorus, other $\mathrm{N}$ sources (Landolfi et al., 2015; Ward et al., 2013), and grazing by zooplankton (Wang et al., 2019), have all been identified as factors shaping the distribution and magnitude of marine $\mathrm{N}_{2}$ 
677 fixation. Although limited in scope and replication, in the temperate southern Australian waters 678 examined here, high $\mathrm{N}_{2}$ fixation rates during the Austral autumn were significantly correlated 679 with increased $\mathrm{PO}_{4}$ concentrations, as was the overall abundance of UCYN-A1 (derived by 680 qPCR). This is consistent with patterns observed in other temperate coastal waters, where $\mathrm{N}_{2}$ 681 fixation has previously been shown to be significantly correlated with phosphorus availability 682 (Tang et al., 2019b). This pattern is also in-line with patterns observed within more oceanic 683 waters, where $\mathrm{PO}_{4}$ availability has been shown to influence nifH expression and $\mathrm{N}_{2}$ fixation rates 684 in experimentally manipulated and natural diazotroph assemblages (Rees et al., 2006; Sañudo685 Wilhelmy et al., 2001; Turk-Kubo et al., 2012; Watkins-Brandt et al., 2011). As phosphorus is an 686 important constituent of cellular and molecular machinery, there is likely a direct causal

687

688

689

690

691

692

693

694

695

696

697

698

699

700

701

702

703

704

705

706

707

708

709

710

711

712

713

714

715

716 relationship between $\mathrm{PO}_{4}$ and $\mathrm{N}_{2}$ fixation, whereby diazotroph abundances and $\mathrm{N}_{2}$ fixation rates are increased under P-replete conditions, as has previously been observed for the UCYN-A1haptophyte symbiosis (Krupke et al., 2015). Within Spencer Gulf, phytoplankton growth is estimated to be limited by $\mathrm{PO}_{4}$ availability year-round (Middleton et al., 2013), indicating that while higher $\mathrm{N}_{2}$ fixation rates may provide a source of bioavailable $\mathrm{N}$ to the dissolved pool, the increased diazotrophic activity may deplete $\mathrm{PO}_{4}$ concentrations for non-diazotrophic microorganisms.

In the present study, overall $\mathrm{N}_{2}$ fixation rates were also negatively correlated with concentrations of $\mathrm{NO}_{3} / \mathrm{NO}_{2}$, which are typically depleted in Gulf waters during Austral summer yet may remain relatively high on the continental shelf due to a permanent deep nutrient pool (Doubell et al., 2018). Spencer Gulf and the adjacent continental shelf waters are characterised by a unique combination of oceanographic and regional circulation processes that create seasonal and localised east-west gradients in ambient concentrations of key macro- and micro-nutrients, underpinning variability in microbial productivity (Doubell et al., 2018; Middleton et al., 2013; van Ruth et al., 2018). During Austral autumn, the density front at the entrance to Spencer Gulf begins to break down and an influx of continental shelf water, relatively rich in macronutrients, enters the Gulf along the western edge, while the oligotrophic Gulf water exits from the eastern side of the mouth (Middleton and Bye, 2007). These north-south and east-west gradients in $\mathrm{NO}_{3} / \mathrm{NO}_{2}$ and $\mathrm{PO}_{4}$ concentrations (low to relatively high, respectively) (Middleton et al., 2013), may explain the observed correlations between $\mathrm{N}_{2}$ fixation rates and these nutrients. This suggests that increased $\mathrm{N}_{2}$ fixation activity may occur due to the low concentrations of bioavailable $\mathrm{N}$, further indicating that $\mathrm{N}$ derived from $\mathrm{N}_{2}$ fixation could sustain productivity within the $\mathrm{N}$ limited Spencer Gulf region. Recently, $\mathrm{N}_{2}$ fixation by UCYN-A was shown to occur even when dissolved inorganic nitrogen sources are replete, and may even be stimulated by increased $\mathrm{NO}_{3}$ concentrations (Mills et al., 2020), highlighting the complexity of factors governing $\mathrm{N}_{2}$ fixation activity in the environment. Collectively, our observations in fact represent the classic nutrient regime within which diazotrophs gain a competitive advantage over nondiazotrophic microorganisms (Ward et al., 2013), utilising excess $\mathrm{PO}_{4}$ and fixing $\mathrm{N}_{2}$ to support growth. 
718 While $\mathrm{PO}_{4}$ and $\mathrm{NO}_{3} / \mathrm{NO}_{2}$ were correlated with rates of $\mathrm{N}_{2}$ fixation at the sites examined in this

719

720

721

722

723

724

725

726

727

728

729

730

731

732

733

734

735

736

737

738

739

740

741

742

743

744

\section{5}

746

747

748

749

750

751

752

753

754

755

756 study, they were not significant predictors of diazotroph assemblage structure. Rather, the structure of the underlying diazotroph community was significantly influenced by the prevailing salinity and $\mathrm{SiO}_{4}$ concentrations. Regional variability in $\mathrm{SiO}_{4}$ concentrations may reflect abiotic indicators of different water masses, and may drive distinct differences in the composition of microbial assemblages (Foster et al., 2007; Weber et al., 2017). The observed transition towards increased non-cyanobacterial diazotrophs in the upper shallow waters of the Gulf could be indicative of their redistribution from the sediment or seagrass microbiome (Brown et al., 2003; Lehnen et al., 2016), and warrants further exploration of their specific activity, source and contribution to $\mathrm{N}$ cycling in Spencer Gulf.

Salinity is a major structuring factor for estuarine microbial communities, driving the transition from freshwater- to marine-adapted lineages (Bouvier and del Giorgio, 2002; Jeffries et al., 2016; Kirchman et al., 2005), and influencing rates of biogeochemical nutrient cycling (Bernhard et al., 2007; Bhavya et al., 2016). Unlike classical estuaries, inverse estuaries such as Spencer Gulf experience hypersaline conditions at the head of the estuary and marine salinities at the mouth, which has previously been shown to influence the overall composition of specific cyanobacterial ecotypes (Messer et al., 2015). In the present study, hypersaline regions of Spencer Gulf were associated with an increase in the relative abundance of non-cyanobacterial diazotrophs and a decrease in the abundance of UCYN-A at sites with salinities $>\sim 37$ PSU, which may reflect an inhibitory effect of high salinity on UCYN-A and it's eukaryotic host. In contrast, members of the deltaproteobacteria, related to the Cluster 3 diazotrophs observed in the present study, have previously been shown to be moderately halophilic (Gam et al., 2009; Warthmann et al., 2005), and their increased relative abundances at the northern most stations of Spencer Gulf suggests they are likely to be halotolerant.

\section{Conclusions}

This study provides further evidence that marine $\mathrm{N}_{2}$ fixation is not limited to tropical and subtropical open ocean environments, yet is widespread throughout diverse, temperate ecosystems, which have previously been overlooked as hotspots of $\mathrm{N}_{2}$ fixation activity. Our results indicate that $\mathrm{N}_{2}$ fixation is influenced by an interplay of physical and chemical environmental variables, which may have direct and indirect effects on the distribution and activity of diazotrophs in coastal waters. Our data revealed notable stability in $\mathrm{N}_{2}$ fixation across contrasting seasons, suggesting that the oligotrophic conditions of southern Australian coastal waters promote diazotrophy within the region. Notably, our findings suggest that pelagic $\mathrm{N}_{2}$ fixation, mediated by UCYN and non-cyanobacterial diazotrophs, could provide a greater source of fixed $\mathrm{N}$ than upwelled and anthropogenic bioavailable $\mathrm{N}$ within the coastal waters of southern Australia. 


\section{Acknowledgements}

760

761

762

763

764

765

766

767

768

769

770

771

772

773

774

775

776

777

778

779

780

781

782

783

784

785

786

787

788

789

790

791

792

793

794

795

796

797

798

799

800

Sampling at NRSKAI and SAM8SG was facilitated by the Integrated Marine Observing System (IMOS). We acknowledge the captain and crew of the South Australian Research and Development Institute (SARDI) RV Ngerin, in particular Paul Malthouse, for their expertise and assistance with sampling during this study. Data was sourced from IMOS, a national collaborative research infrastructure, supported by the Australian Government.

\section{References}

Ahmed, A., Naik, H., Adel, S. S., Bardhan, P., Gauns, M., Naik, B., and Naqvi, S. (2019). Nitrogen fixation and carbon uptake in a tropical estuarine system of Goa, western India. $J$. Sea Res. 144, 16-21. doi:10.1016/j.seares.2018.09.018.

Bentzon-Tilia, M., Farnelid, H., Jürgens, K., and Riemann, L. (2014). Cultivation and isolation of N2-fixing bacteria from suboxic waters in the Baltic Sea. FEMS Microbiol. Ecol. 88, 358-371. doi:10.1111/1574-6941.12304.

Bentzon-Tilia, M., Severin, I., and Hansen, L. H. (2015a). Genomics and Ecophysiology of Heterotrophic Nitrogen-Fixing Bacteria Isolated from Estuarine Surface Water. MBio 6, 111. doi:10.1128/mBio.00929-15.Editor.

Bentzon-Tilia, M., Traving, S. J., Mantikci, M., Knudsen-Leerbeck, H., Hansen, J. L. S., Markager, S., and Riemann, L. (2015b). Significant $\mathrm{N}_{2}$ fixation by heterotrophs, photoheterotrophs and heterocystous cyanobacteria in two temperate estuaries. ISME J. 9, 273-285. doi:10.1038/ismej.2014.119.

Bernhard, A. E., Tucker, J., Giblin, A. E., and Stahl, D. A. (2007). Functionally distinct communities of ammonia-oxidizing bacteria along an estuarine salinity gradient. Environ. Microbiol. 9, 1439-1447. doi:10.1111/j.1462-2920.2007.01260.x.

Berthelot, H., Bonnet, S., Camps, M., Grosso, O., and Moutin, T. (2015). Assessment of the dinitrogen released as ammonium and dissolved organic nitrogen by unicellular and filamentous marine diazotrophic cyanobacteria grown in culture. Front. Mar. Sci. 2. doi:10.3389/fmars.2015.00080.

Bhavya, P. S., Kumar, S., Gupta, G. V. M., Sudheesh, V., Sudharma, K. V., Varrier, D. S., Dhanya, K.R., and Saravanane, N. (2016). Nitrogen Uptake Dynamics in a Tropical Eutrophic Estuary (Cochin, India) and Adjacent Coastal Waters. Estuaries and Coasts 39, 54-67. doi:10.1007/s12237-015-9982-y.

Bird, C., and Wyman, M. (2013). Transcriptionally active heterotrophic diazotrophs are widespread in the upper water column of the Arabian Sea. FEMS Microbiol. Ecol. 84, 189200. doi:10.1111/1574-6941.12049.

Bombar, D., Paerl, R. W., and Riemann, L. (2016). Marine Non-Cyanobacterial Diazotrophs: Moving beyond Molecular Detection. Trends Microbiol. 24, 916-927. doi:10.1016/j.tim.2016.07.002.

Bonnet, S., Rodier, M., Turk-Kubo, K. A., Germineaud, C., Menkes, C., Ganachaud, A., Cravatte S., Raimbault P., Campbell E., Quéroué F., Sarthou G., Desnues A., Maes C., Eldin G. (2015). Contrasted geographical distribution of $\mathrm{N}_{2}$ fixation rates and nifH 
801

802

803

804

805

806

807

808

809

810

811

812

813

814

815

816

817

818

819

820

821

822

823

824

825

826

827

828

829

830

831

832

833

834

835

836

837

838

839

840

841

842

843

844

845

846 phylotypes in the Coral and Solomon Seas (southwestern Pacific) during austral winter conditions. Global Biogeochem. Cycles 29, 1874-1892. doi:10.1002/2015GB005117.

Böttjer, D., Dore, J. E., Karl, D. M., Letelier, R. M., Mahaffey, C., Wilson, S. T., Zehr J., Church M. J. (2017). Temporal variability of nitrogen fixation and particulate nitrogen export at Station ALOHA. Limnol. Oceanogr. 62, 200-216. doi:10.1002/lno.10386.

Bouvier, T., and del Giorgio, P. (2002). Compositional changes in free-living bacterial communities along a salinity gradient in two temperate estuaries. Limnol. Oceanogr. 47, 453-470.

Breitbarth, E., Oschlies, A., and LaRoche, J. (2007). Physiological constraints on the global distribution of Trichodesmium - Effect of temperature on diazotrophy. Biogeosciences 4, 53-61. doi:10.5194/bg-4-53-2007.

Brown, M. M., Friez, M. J., and Lovell, C. R. (2003). Expression of nifH genes by diazotrophic bacteria in the rhizosphere of short form Spartina alterniflora. FEMS Microbiology Ecology, 43(3), 411-417. https://doi.org/10.1016/S0168-6496(02)00447-6

Caffin, M., Berthelot, H., Cornet-Barthaux, V., Barani, A., and Bonnet, S. (2018). Transfer of diazotroph-derived nitrogen to the planktonic food web across gradients of $\mathrm{N}_{2}$ fixation activity and diversity in the western tropical South Pacific Ocean. Biogeosciences 15, 37953810. doi:10.5194/bg-15-3795-2018.

Capone, D. G., Burns, J. A., Montoya, J. P., Subramaniam, A., Mahaffey, C., Gunderson, T., Michaels A. F., Carpenter E. J. (2005). Nitrogen fixation by Trichodesmium spp.: An important source of new nitrogen to the tropical and subtropical North Atlantic Ocean. Global Biogeochem. Cycles 19, GB2024. doi:10.1029/2004GB002331.

Caporaso, J., Bittinger, K., Bushman, F. D., Desantis, T. Z., Andersen, G. L., and Knight, R. (2010a). PyNAST: A flexible tool for aligning sequences to a template alignment. Bioinformatics 26, 266-267. doi:10.1093/bioinformatics/btp636.

Caporaso, J., Kuczynski, J., Stombaugh, J., Bittinger, K., Bushman, F., Costello, E. K., Fierer N., Gonzalez Pena A., Goodrich J., Gordon J. I., Huttley G., Kelley S. T. (2010b). QIIME allows analysis of high-throughput community sequencing data. Nat. Methods 7, 335-336. doi:10.1038/nmeth0510-335.

Chen, T.-Y., Chen, Y. L., Sheu, D.-S., Chen, H.-Y., Lin, Y.-H., and Shiozaki, T. (2018). Community and abundance of heterotrophic diazotrophs in the northern South China Sea: revealing the potential importance of a new alphaproteobacterium in $\mathrm{N}_{2}$ fixation. Deep Sea Res. Part I Oceanogr. Res. Pap. doi:10.1016/j.dsr.2018.11.006.

Condie, S. A., and Dunn, J. R. (2006). Seasonal characteristics of the surface mixed layer in the Australasian region: Implications for primary production regimes and biogeography. Mar. Freshw. Res. 57, 569-590. doi:10.1071/MF06009.

Cornejo-Castillo, F. M., Muñoz-Marín, M. del C., Turk-Kubo, K. A., Royo-Llonch, M., Farnelid, H., Acinas, S. G., Zehr J. P. (2018). UCYN-A3, a newly characterized open ocean sublineage of the symbiotic $\mathrm{N}_{2}$-fixing cyanobacterium Candidatus Atelocyanobacterium thalassa. Environ. Microbiol. 00. doi:10.1111/1462-2920.14429.

Deloitte Access Economics. (2017). The Economic Contribution of South Australia's Marine Industries. 1-52. Deloitte Touche Tohmatsu, November 2017. Available at: http://www.misa.net.au/_data/assets/pdf_file/0004/324949/DAE_South_Australias_Marin e_Industries_Print_May $\overline{18}$.pdf.

Delmont, T. O., Quince, C., Shaiber, A., Esen, Ö. C., Lee, S. T., Rappé, M. S., MacLellan S. L., Lücker S., Eren A. M. (2018). Nitrogen-fixing populations of Planctomycetes and 
847

848

849

850

851

852

853

854

855

856

857

858

859

860

861

862

863

864

865

866

867

868

869

870

871

872

873

874

875

876

877

878

879

880

881

882

883

884

885

886

887

888

889

890

891

892

Proteobacteria are abundant in surface ocean metagenomes. Nat. Microbiol. 3, 804-813. doi:10.1038/s41564-018-0176-9.

Díez, B., Bergman, B., Pedrós-Alió, C., Antó, M., and Snoeijs, P. (2012). High cyanobacterial nifH gene diversity in Arctic seawater and sea ice brine. Environ. Microbiol. Rep. 4, 360-6. doi:10.1111/j.1758-2229.2012.00343.x.

Doubell, M. J., Spencer, D., van Ruth, P. D., Lemckert, C., and Middleton, J. F. (2018). Observations of vertical turbulent nitrate flux during summer in the Great Australian Bight. Deep. Res. Part II Top. Stud. Oceanogr. 157-158, 27-35. doi:10.1016/j.dsr2.2018.08.007.

Edgar, R. C. (2010). Search and clustering orders of magnitude faster than BLAST. Bioinformatics 26, 2460-1. doi:10.1093/bioinformatics/btq461.

Eugster, O., and Gruber, N. (2012). A probabilistic estimate of global marine $\mathrm{N}_{2}$-fixation and denitrification. Global Biogeochem. Cycles 26, 1-15. doi:10.1029/2012GB004300.

Eyre, B. (1998). Transport, Retention and Transformation of Material in Australian Estuaries. Estuaries 21, 540. doi:10.2307/1353293.

Farnelid, H., Andersson, A. F., Bertilsson, S., Al-Soud, W. A., Hansen, L. H., Sørensen, S., Steward G. F., Hagström Å., Riemann L. (2011). Nitrogenase gene amplicons from global marine surface waters are dominated by genes of non-cyanobacteria. PLoS One 6. doi:10.1371/journal.pone.0019223.

Farnelid, H., Bentzon-Tilia, M., Andersson, A. F., Bertilsson, S., Jost, G., Labrenz, M., Jürgens K., Riemann L. (2013). Active nitrogen-fixing heterotrophic bacteria at and below the chemocline of the central Baltic Sea. ISME J. 7, 1413-1423. doi:10.1038/ismej.2013.26.

Farnelid, H., Harder, J., Bentzon-Tilia, M., and Riemann, L. (2014). Isolation of heterotrophic diazotrophic bacteria from estuarine surface waters. Environ. Microbiol. 16, 3072-3082. doi:10.1111/1462-2920.12335.

Farnelid, H., Turk-Kubo, K., Del Carmen Muñoz-Marín, M., and Zehr, J. P. (2016). New insights into the ecology of the globally significant uncultured nitrogen-fixing symbiont UCYN-A. Aquat. Microb. Ecol. 77, 128-138. doi:10.3354/ame01794.

Fernandes, M., Lauer, P., Cheshire, A., and Angove, M. (2007). Preliminary model of nitrogen loads from southern bluefin tuna aquaculture. Mar. Pollut. Bull. 54, 1321-1332. doi:10.1016/j.marpolbul.2007.06.005.

Fernández-Méndez, M., Turk-Kubo, K. A., Buttigieg, P. L., Rapp, J. Z., Krumpen, T., Zehr, J. P., Boetius A. (2016). Diazotroph diversity in the sea ice, melt ponds, and surface waters of the eurasian basin of the Central Arctic Ocean. Front. Microbiol. 7, 1-18. doi:10.3389/fmicb.2016.01884.

Fernandez, C., Lorena González, M., Munoz, C., Molina, V., and Farías, L. (2015). Temporal and spatial variability of biological nitrogen fixation off the upwelling systemof central Chile (35-38.5oS). J. Geophys. Res. Ocean. 120, 3330-3349. doi:10.1002/2014JC010410.Received.

Fish, J. A., Chai, B., Wang, Q., Sun, Y., Brown, C. T., Tiedje, J. M., Cole J. R. (2013). FunGene: The functional gene pipeline and repository. Front. Microbiol. 4, 1-14. doi:10.3389/fmicb.2013.00291.

Fonseca-Batista, D., Li, X., Riou, V., Michotey, V., Deman, F., Fripiat, F., Guasco S., Brion N., Lemaitre N., Tonnard M., Gallinari M., Planquette H., Planchon F., Sarthou G., Elskens M., Laroche J., Chou L., Dehairs F. (2019). Evidence of high $\mathrm{N}_{2}$ fixation rates in the temperate northeast Atlantic. Biogeosciences 16, 999-1017. doi:10.5194/bg-16-999-2019.

Foster, R. A., Kuypers, M. M. M., Vagner, T., Paerl, R. W., Musat, N., and Zehr, J. P. (2011).

Peer] reviewing PDF | (2020:05:48794:2:0:NEW 17 Dec 2020) 
893

894

895

896

897

898

899

900

901

902

903

904

905

906

907

908

909

910

911

912

913

914

915

916

917

918

919

920

921

922

923

924

925

926

927

928

929

930

931

932

933

934

935

936

937

938

Nitrogen fixation and transfer in open ocean diatom-cyanobacterial symbioses. ISME J. 5, 1484-1493. doi:10.1038/ismej.2011.26.

Foster, R. A., Subramaniam, A., Mahaffey, C., Carpenter, E. J., Capone, D. G., and Zehr, J. P. (2007). Influence of the Amazon River plume on distributions of free-living and symbiotic cyanobacteria in the western tropical north Atlantic Ocean. Limnol. Oceanogr. 52, 517-532. doi:10.4319/10.2007.52.2.0517.

Gam, Z. B. A., Oueslati, R., Abdelkafi, S., Casalot, L., Tholozan, J. L., and Labat, M. (2009). Desulfovibrio tunisiensis sp. nov., a novel weakly halotolerant, sulfate-reducing bacterium isolated from exhaust water of a Tunisian oil refinery. Int. J. Syst. Evol. Microbiol. 59, 1059-1063. doi:10.1099/ijs.0.000943-0.

Garcia, N., Raimbault, P., and Sandroni, V. (2007). Seasonal nitrogen fixation and primary production in the Southwest Pacific: Nanoplankton diazotrophy and transfer of nitrogen to picoplankton organisms. Mar. Ecol. Prog. Ser. 343, 25-33. doi:10.3354/meps06882.

Glibert, P. M., and Bronk, D. A. (1994). Release of dissolved organic nitrogen by marine diazotrophic cyanobacteria, Trichodesmium spp. Appl. Environ. Microbiol. 60, 3996-4000.

Goebel, N. L., Turk, K. A., Achilles, K. M., Paerl, R., Hewson, I., Morrison, A. E., Montoya J. P., Edwards C. A., Zehr J. P. (2010). Abundance and distribution of major groups of diazotrophic cyanobacteria and their potential contribution to $\mathrm{N}_{2}$ fixation in the tropical Atlantic Ocean. Environ. Microbiol. 12, 3272-89. doi:10.1111/j.1462-2920.2010.02303.x.

Gradoville, M. R., Bombar, D., Crump, B. C., Letelier, R. M., Zehr, J. P., and White, A. E. (2017). Diversity and activity of nitrogen-fixing communities across ocean basins. Limnol. Oceanogr. 62, 1895-1909. doi:10.1002/lno.10542.

Großkopf, T., Mohr, W., Baustian, T., Schunck, H., Gill, D., Kuypers, M. M. M., Lavik G., Schmitz R. A., Wallace D. W. R., LaRoche J. (2012). Doubling of marine dinitrogenfixation rates based on direct measurements. Nature 488, 361-364. doi:10.1038/nature11338.

Harding, K., Turk-Kubo, K. A., Sipler, R. E., Mills, M. M., Bronk, D. A., and Zehr, J. P. (2018). Symbiotic unicellular cyanobacteria fix nitrogen in the Arctic Ocean. Proc. Natl. Acad. Sci. U. S. A. 115, 13371-13375. doi:10.1073/pnas.1813658115.

Heller, P., Tripp, H. J., Turk-Kubo, K., and Zehr, J. P. (2014). ARBitrator: A software pipeline for on-demand retrieval of auto-curated nifH sequences from GenBank. Bioinformatics 30, 1-8. doi:10.1093/bioinformatics/btu417.

Howarth, R. W., Marino, R., Lane, J., and Cole, J. J. (1988). Nitrogen fixation in freshwater, estuarine, and marine ecosystems. 1. Rates and importance. Limnol. Oceanogr. 33, 669687. doi:10.4319/1o.1988.33.4_part_2.0669.

Jayakumar, A., Chang, B. X., Widner, B., Bernhardt, P., Mulholland, M. R., and Ward, B. B. (2017). Biological nitrogen fixation in the oxygen-minimum region of the eastern tropical North Pacific ocean. ISME J. 11, 2356-2367. doi:10.1038/ismej.2017.97.

Jeffries, T. C., Schmitz Fontes, M. L., Harrison, D. P., Van-Dongen-Vogels, V., Eyre, B. D., Ralph, P. J., Seymour J. R. (2016). Bacterioplankton dynamics within a large anthropogenically impacted urban estuary. Front. Microbiol. 6, 1-17. doi:10.3389/fmicb.2015.01438.

Jickells, T. D. (1998). Nutrient biogeochemistry of the coastal zone. Science (80-. ). 281, $217-$ 222. doi:10.1126/science.281.5374.217.

Karl, D. M., Church, M. J., Dore, J. E., Letelier, R. M., and Mahaffey, C. (2012). Predictable and efficient carbon sequestration in the North Pacific Ocean supported by symbiotic nitrogen 
939

940

941

942

943

944

945

946

947

948

949

950

951

952

953

954

955

956

957

958

959

960

961

962

963

964

965

966

967

968

969

970

971

972

973

974

975

976

977

978

979

980

981

982

983

984

fixation. Proc. Natl. Acad. Sci. U. S. A. 109, 1842-9. doi:10.1073/pnas.1120312109.

Karl, D., Michaels, A., Bergman, B., Capone, D., Carpenter, E., Letelier, R., Lipschultz F., Paerl H., Sigman D., Stal L. (2002). Dinitrogen fixation in the world's oceans. Biogeochemistry 57-58, 47-98. doi:10.1023/A:1015798105851.

Kirchman, D. L., Dittel, A. I., Malmstrom, R. R., and Cottrell, M. T. (2005). Biogeography of major bacterial groups in the Delaware Estuary. Limnol. Oceanogr. 50, 1697-1706. doi:10.4319/lo.2005.50.5.1697.

Klawonn, I., Lavik, G., Böning, P., Marchant, H. K., Dekaezemacker, J., Mohr, W., Ploug H. (2015). Simple approach for the preparation of 15-15N2-enriched water for nitrogen fixation assessments: Evaluation, application and recommendations. Front. Microbiol. 6, 111. doi:10.3389/fmicb.2015.00769.

Knapp, A. N. (2012). The sensitivity of marine N2 fixation to dissolved inorganic nitrogen. Front. Microbiol. 3, 1-14. doi:10.3389/fmicb.2012.00374.

Krupke, A., Mohr, W., Laroche, J., Fuchs, B. M., Amann, R. I., and Kuypers, M. M. M. (2015). The effect of nutrients on carbon and nitrogen fixation by the UCYN-A - haptophyte symbiosis. ISME J. 9, 1635-1647. doi:10.1038/ismej.2014.253.

Landolfi, A., Koeve, W., Dietze, H., Kähler, P., and Oschlies, A. (2015). A new perspective on environmental controls of marine nitrogen fixation. Geophys. Res. Lett. 42, 4482-4489. doi:10.1002/2015GL063756.

Langlois, R., Großkopf, T., Mills, M., Takeda, S., and LaRoche, J. (2015). Widespread Distribution and Expression of Gamma A (UMB), an Uncultured, Diazotrophic, $\gamma$ Proteobacterial nifH Phylotype. PLoS One 10, e0128912. doi:10.1371/journal.pone.0128912.

Langlois, R. J., Hummer, D., and LaRoche, J. (2008). Abundances and Distributions of the Dominant nifH Phylotypes in the Northern Atlantic Ocean. Appl. Environ. Microbiol. 74, 1922-1931. doi:10.1128/AEM.01720-07.

Lauer, P. R., Fernandes, M., Fairweather, P. G., Tanner, J., and Cheshire, A. (2009). Benthic fluxes of nitrogen and phosphorus at southern bluefin tuna Thunnus maccoyii sea-cages. Mar. Ecol. Ser. 390, 251-263. doi:10.3354/meps08186.

Lehnen, N., Marchant, H. K., Schwedt, A., Milucka, J., Lott, C., Weber, M., Dekaezemacker, J., Seah, B. K. B., Hach, P. F., Mohr, W., \& Kuypers, M. M. M. (2016). High rates of microbial dinitrogen fixation and sulfate reduction associated with the Mediterranean seagrass Posidonia oceanica. Systematic and Applied Microbiology, 39(7), 476-483. https://doi.org/10.1016/j.syapm.2016.08.004.

Luo, Y.-W., Doney, S. C., Anderson, L. A., Benavides, M., Berman-Frank, I., Bode, A., Bonnet S., Boström K. H., Böttjer D., Capone D. G., Carpenter E. J., Chen Y. L., Church M. J., Dore J. E., Falcón L. I., Fernández A., Foster R. A., Furuya K., Gómez F., Gundersen K., Hynes A. M., Karl D. M., Kitajima S., Langlois R. J., LaRoche J., Letelier R. M., Marañón E., McGillicuddy D. J., Moisander P. H., Moore C. M., Mouriño-Carballido B., Mulholland M. R., Needoba J. A., Orcutt K. M., Poulton A. J., Rahav E., Raimbault P., Rees A. P., Riemann L., Shiozaki T., Subramaniam A., Tyrrell T., Turk-Kubo K. A., Varela M., Villareal T. A., Webb E. A., White A. E., Wu J., Zehr J. P. (2012). Database of diazotrophs in global ocean: abundance, biomass and nitrogen fixation rates. Earth Syst. Sci. Data 4, 47-73. doi:10.5194/essd-4-47-2012.

Luo, Y. W., Lima, I. D., Karl, D. M., Deutsch, C. A., and Doney, S. C. (2014). Data-based assessment of environmental controls on global marine nitrogen fixation. Biogeosciences

PeerJ reviewing PDF | (2020:05:48794:2:0:NEW 17 Dec 2020) 
985

986

987

988

989

990

991

992

993

994

995

996

997

998

999

1000

1001

1002

1003

1004

1005

1006

1007

1008

1009

1010

1011

1012

1013

1014

1015

1016

1017

1018

1019

1020

1021

1022

1023

1024

1025

1026

1027

1028

1029

1030

11, 691-708. doi:10.5194/bg-11-691-2014.

Lynch, T. P., Morello, E. B., Evans, K., Richardson, A. J., Rochester, W., Steinberg, C. R., Roughan M., Thompson P., Middleton J. F., Feng M., Sherrington R., Brando V., Tilbrook B., Ridgway K., Allen S., Doherty P., Hill K., Moltmann T. C. (2014). IMOS National Reference Stations: A continental-wide physical, chemical and biological coastal observing system. PLoS One 9, 1-28. doi:10.1371/journal.pone.0113652.

Messer, L. F., Brown, M. V., Furnas, M. J., Carney, R. L., McKinnon, A. D., and Seymour, J. R. (2017). Diversity and activity of diazotrophs in great barrier reef surface waters. Front. Microbiol. 8, 1-16. doi:10.3389/fmicb.2017.00967.

Messer, L. F., Doubell, M., Jeffries, T. C., Brown, M. V, and Seymour, J. R. (2015). Prokaryotic and diazotrophic population dynamics within a large oligotrophic inverse estuary. Aquat. Microb. Ecol. 74, 1-15. doi:10.3354/ame01726.

Messer, L. F., Mahaffey, C., Robinson, C. M., Jeffries, T. C., Baker, K. G., Isaksson, J. B., Ostrowski M., Doblin MA., Brown M V., Seymour JR. (2016). High levels of heterogeneity in diazotroph diversity and activity within a putative hotspot for marine nitrogen fixation. ISME J. 10, 1499-1513. doi:10.1038/ismej.2015.205.

Middleton, J., Doubell, M., James, C., Luick, J., and Ruth, P. Van (2013). PIRSA Initiative II: carrying capacity of Spencer Gulf: hydrodynamic and biogeochemical measurement modelling and performance monitoring. Final Report for the Fisheries Research and Development Corporation.

Middleton, J. F., and Bye, J. A. T. (2007). A review of the shelf-slope circulation along Australia's southern shelves: Cape Leeuwin to Portland. Prog. Oceanogr. 75, 1-41. doi:10.1016/j.pocean.2007.07.001.

Mills, M. M., Turk-Kubo, K. A., van Dijken, G. L., Henke, B. A., Harding, K., Wilson, S. T., Arrigo, K. R., \& Zehr, J. P. (2020). Unusual marine cyanobacteria/haptophyte symbiosis relies on $\mathrm{N} 2$ fixation even in N-rich environments. ISME J, 3. https://doi.org/10.1038/s41396-020-0691-6.

Mohr, W., Großkopf, T., Wallace, D. W. R., and LaRoche, J. (2010). Methodological Underestimation of Oceanic Nitrogen Fixation Rates. PLoS One 5, e12583. doi:10.1371/journal.pone.0012583.

Moisander, P. H., Beinart, R. A., Hewson, I., White, A. E., Johnson, K. S., Carlson, C. A., Montoya J. P., Zehr J.P. (2010). Unicellular cyanobacterial distributions broaden the oceanic $\mathrm{N}_{2}$ fixation domain. Science 327, 1512-1514. doi:10.1126/science.1185468.

Moisander, P. H., Serros, T., Paerl, R. W., Beinart, R. A., and Zehr, J. P. (2014). Gammaproteobacterial diazotrophs and nifH gene expression in surface waters of the South Pacific Ocean. ISME J. 8, 1962-1973. doi:10.1038/ismej.2014.49.

Monteiro, F. M., Dutkiewicz, S., and Follows, M. J. (2011). Biogeographical controls on the marine nitrogen fixers. Global Biogeochem. Cycles 25, 1-8. doi:10.1029/2010GB003902.

Montoya, J., Holl, C., Zehr, J., and Hansen, A. (2004). High rates of $\mathrm{N}_{2}$ fixation by unicellular diazotrophs in the oligotrophic Pacific Ocean. Nature 430, 1027-1031. doi:10.1038/nature02744.1.

Montoya, J. P., Voss, M., Kahler, P., and Capone, D. G. (1996). A Simple, High-Precision, High-Sensitivity Tracer Assay for N2 Fixation. Appl. Environ. Microbiol. 62, 986-93.

Moore, C. M., Mills, M. M., Arrigo, K. R., Berman-Frank, I., Bopp, L., Boyd, P. W., Galbraith E. D., Geider R. J., Guieu C., Jaccard S. L., Jickells T. D., LaRoche J., Lenton T. M., Mahowald N. M., Marañón E., Marinov I., Moore J. K., Nakatsuka T., Oschlies A., Saito

Peer) reviewing PDF | (2020:05:48794:2:0:NEW 17 Dec 2020) 
1031

1032

1033

1034

1035

1036

1037

1038

1039

1040

1041

1042

1043

1044

1045

1046

1047

1048

1049

1050

1051

1052

1053

1054

1055

1056

1057

1058

1059

1060

1061

1062

1063

1064

1065

1066

1067

1068

1069

1070

1071

1072

1073

1074

1075

1076

M. A., Thingstad T. F., Tsuda A., Ulloa O. (2013). Processes and patterns of oceanic nutrient limitation. Nat. Geosci. 6, 701-710. doi:10.1038/ngeo1765.

Mulholland, M. R., Bronk, D. A, and Capone, D. G. (2004). Dinitrogen fixation and release of ammonium and dissolved organic nitrogen by Trichodesmium IMS101. Aquat. Microb. Ecol. 37, 85-94.

Mulholland, M. R. (2007). The fate of nitrogen fixed by diazotrophs in the ocean. Biogeosciences 4, 37-51. doi:10.5194/bg-4-37-2007.

Mulholland, M. R., Bernhardt, P. W., Blanco-Garcia, J. L., Mannino, A., Hyde, K., Mondragon, E., Turk K., Moisander P. H., Zehr J. P. (2012). Rates of dinitrogen fixation and the abundance of diazotrophs in North American coastal waters between Cape Hatteras and Georges Bank. Limnol. Oceanogr. 57, 1067-1083. doi:10.4319/lo.2012.57.4.1067.

Mulholland, M. R., Bernhardt, P. W., Widner, B. N., Selden, C. R., Chappell, P. D., Clayton, S., Mannino A., Hyde K. (2019). High rates of $\mathrm{N}_{2}$ fixation in temperate, western North Atlantic coastal waters expands the realm of marine diazotrophy. Global Biogeochemical Cycles, 33, 826-840. doi:10.1029/2018GB006130.

Needoba, J. A., Foster, R. A., Sakamoto, C., Zehr, J. P., and Johnson, K. S. (2007). Nitrogen fixation by unicellular diazotrophic cyanobacteria in the temperate oligotrophic North Pacific Ocean. Limnol. Oceanogr. 52, 1317-1327. doi:10.4319/1o.2007.52.4.1317.

Nunes, R. A., and Lennon, G. W. (1986). Physical property distributions and seasonal trends in Spencer Gulf, South Australia: an inverse estuary. Mar. Freshw. Res. 37, 39-53. doi:doi:10.1071/MF9860039.

Nunes Vaz, R. A., Lennon, G. W., and Bowers, D. G. (1990). Physical behaviour of a large, negative or inverse estuary. Cont. Shelf Res. 10, 277-304. doi:10.1016/02784343(90)90023-F.

Paerl, H. W., Crocker, K. M., and Prufert, L. E. (1987). Limitation of $\mathrm{N}_{2}$ fixation in coastal marine waters: Relative importance of molybdenum, iron, phosphorus, and organic matter availability. Limnol. Oceanogr. 32, 525-536. doi:10.4319/10.1987.32.3.0525.

Paxinos, R. (2007). Dynamics of phytoplankton in relation to tuna fish farms in Boston Bay and near-shore Spencer Gulf, South Australia. 172p. PhD Thesis, Flinders University of South Australia.

Petrusevics, P., Bye, J., Luick, J., and Teixeira, C. E. P. (2011). Summer sea surface temperature fronts and elevated chlorophyll-a in the entrance to Spencer Gulf, South Australia. Cont. Shelf Res. 31, 849-856. doi:10.1016/j.csr.2011.02.009.

Petrusevics, P. M. (1993). SST Fronts in Inverse Estuaries, South Australia- Indicators of Reduced Gulf-Shelf Exchange. Aust. J. Mar. Freshw. Res. 44, 305-323.

Pritchard, D. (1952). Estuarine Hydrography. Adv. Geophys. 1, 243-280.

R Core Team (2013) R: A Language and Environment for Statistical Computing. R Foundation for Statistical Computing, Vienna. http://www.R-project.org/

Raes, E. J., Thompson, P. A., McInnes, A. S., Nguyen, H. M., Hardman-Mountford, N., and Waite, A. M. (2015). Sources of new nitrogen in the Indian Ocean. Global Biogeochem. Cycles 29, 1283-1297. doi:10.1002/2015GB005194.Received.

Raes, E. J., Waite, A. M., McInnes, A. S., Olsen, H., Nguyen, H. M., Hardman-Mountford, N., Thompson P. A. (2014). Changes in latitude and dominant diazotrophic community alter $\mathrm{N}_{2}$ fixation. Mar. Ecol. Prog. Ser. 516, 85-102. doi:10.3354/meps11009.

Rees, A. P., Gilbert, J. A., and Kelly-Gerreyn, B. A. (2009). Nitrogen fixation in the western English Channel (NE Atlantic Ocean). Mar. Ecol. Prog. Ser. 374, 7-12.

Peer) reviewing PDF | (2020:05:48794:2:0:NEW 17 Dec 2020) 
1077

1078

1079

1080

1081

1082

1083

1084

1085

1086

1087

1088

1089

1090

1091

1092

1093

1094

1095

1096

1097

1098

1099

1100

1101

1102

1103

1104

1105

1106

1107

1108

1109

1110

1111

1112

1113

1114

1115

1116

1117

1118

1119

1120

1121

1122

doi: $10.3354 /$ meps07771.

Rees, A. P., Law, C. S., and Woodward, E. M. S. (2006). High rates of nitrogen fixation during an in-situ phosphate release experiment in the Eastern Mediterranean Sea. Geophys. Res. Lett. 33, n/a-n/a. doi:10.1029/2006GL025791.

Rivero-Calle, S., Del Castillo, C. E., Gnanadesikan, A., Dezfuli, A., Zaitchik, B., and Johns, D. G. (2016). Interdecadal Trichodesmium variability in cold North Atlantic waters. Global Biogeochem. Cycles 30, 1620-1638. doi:10.1002/2015GB005361.

Robbins, W. D., Huveneers, C., Parra, G. J., Möller, L., and Gillanders, B. M. (2017). Anthropogenic threat assessment of marine-associated fauna in Spencer Gulf, South Australia. Mar. Policy 81, 392-400. doi:10.1016/j.marpol.2017.03.036.

Sañudo-Wilhelmy, S. A., Kustka, A. B., Gobler, C. J., Hutchins, D. A., Yang, M., Lwiza, K., Burns J., Capone D. G., Raven J. A., Carpenter E. J. (2001). Phosphorus limitation of nitrogen fixation by Trichodesmium in the central Atlantic Ocean. Nature 411, 66-69. doi:10.1038/35075041.

Schlitzer, R., (2018). Ocean Data View, https://odv.awi.de, 2018

Severin, I., Bentzon-Tilia, M., Moisander, P. H., and Riemann, L. (2015). Nitrogenase expression in estuarine bacterioplankton influenced by organic carbon and availability of oxygen. FEMS Microbiol. Lett. 362, 1-7. doi:10.1093/femsle/fnv105.

Shiozaki, T., Bombar, D., Riemann, L., Hashihama, F., Takeda, S., Yamaguchi, T., Ehama M., Hamasaki K., Furuya K. (2017). Basin scale variability of active diazotrophs and nitrogen fixation in the North Pacific, from the tropics to the subarctic Bering Sea. Global Biogeochem. Cycles 31, 996-1009. doi:10.1002/2017GB005681.

Shiozaki, T., Nagata, T., Ijichi, M., and Furuya, K. (2015a). Nitrogen fixation and the diazotroph community in the temperate coastal region of the northwestern North Pacific. Biogeosciences 12, 4751-4764. doi:10.5194/bgd-12-865-2015.

Shiozaki, T., Nagata, T., Ijichi, M., and Furuya, K. (2015b). Seasonal dynamics of nitrogen fixation and the diazotroph community in the temperate coastal region of the northwestern North Pacific. Biogeosciences Discuss. 12, 865-889. doi:10.5194/bgd-12-865-2015.

Short, S. M., and Zehr, J. P. (2007). Nitrogenase gene expression in the Chesapeake Bay Estuary. Environ. Microbiol. 9, 1591-1596. doi:10.1111/j.1462-2920.2007.01258.x.

Singh, A., Gandhi, N., and Ramesh, R. (2019). Surplus supply of bioavailable nitrogen through $\mathrm{N}_{2}$ fixation to primary producers in the eastern Arabian Sea during autumn. Cont. Shelf Res. 181, 103-110. doi:10.1016/j.csr.2019.05.012.

Smith, S. V, and Veeh, H. H. (1989). Mass balance of biogeochemically active materials (C, N, P) in a hypersaline gulf. Estuar. Coast. Shelf Sci. 29, 195-215. doi:10.1016/02727714(89)90053-X.

Sohm, J. A., Webb, E. A., and Capone, D. G. (2011). Emerging patterns of marine nitrogen fixation. Nat. Rev. Microbiol. 9, 499-508. doi:10.1038/nrmicro2594.

Stenegren, M., Caputo, A., Berg, C., Bonnet, S., \& Foster, R. A. (2018). Distribution and drivers of symbiotic and free-living diazotrophic cyanobacteria in the western tropical South Pacific. Biogeosciences, 15(5), 1559-1578. https://doi.org/10.5194/bg-15-1559-2018

Stewart, F. J., Ottesen, E. A., and Delong, E. F. (2010). Development and quantitative analyses of a universal rRNA-subtraction protocol for microbial metatranscriptomics. ISME J. 4, 896-907. doi:10.1038/ismej.2010.18.

Tang, W., Li, Z., and Cassar, N. (2019a). Machine Learning Estimates of Global Marine Nitrogen Fixation. J. Geophys. Res. Biogeosciences 124, 717-730. 
1123

1124

1125

1126

1127

1128

1129

1130

1131

1132

1133

1134

1135

1136

1137

1138

1139

1140

1141

1142

1143

1144

1145

1146

1147

1148

1149

1150

1151

1152

1153

1154

1155

1156

1157

1158

1159

1160

1161

1162

1163

1164

1165

1166

1167

1168

doi:10.1029/2018JG004828.

Tang, W., Wang, S., Fonseca-Batista, D., Dehairs, F., Gifford, S., Gonzalez, A. G., Gallinari M., Planquette H., Sarthou G., Cassar N. (2019b). Revisiting the distribution of oceanic $\mathrm{N}_{2}$ fixation and estimating diazotrophic contribution to marine production. Nat. Commun. 10, 1-10. doi:10.1038/s41467-019-08640-0.

Taniuchi, Y., Chen, Y. L. L., Chen, H. Y., Tsai, M. L., \& Ohki, K. (2012). Isolation and characterization of the unicellular diazotrophic cyanobacterium Group C TW3 from the tropical western Pacific Ocean. Environmental Microbiology, 14(3), 641-654. https://doi.org/10.1111/j.1462-2920.2011.02606.x

Thompson, A., Carter, B. J., Turk-Kubo, K., Malfatti, F., Azam, F., and Zehr, J. P. (2014). Genetic diversity of the unicellular nitrogen-fixing cyanobacteria UCYN-A and its prymnesiophyte host. Environ. Microbiol. 16, 3238-3249. doi:10.1111/1462-2920.12490.

Turk-Kubo, K. A., Achilles, K. M., Serros, T. R. C., Ochiai, M., Montoya, J. P., and Zehr, J. P. (2012). Nitrogenase ( $n$ ifH) gene expression in diazotrophic cyanobacteria in the Tropical North Atlantic in response to nutrient amendments. Front. Microbiol. 3, 1-17. doi:10.3389/fmicb.2012.00386.

Turk-Kubo, K. A., Farnelid, H. M., Shilova, I. N., Henke, B., and Zehr, J. P. (2016). Distinct ecological niches of marine symbiotic $\mathrm{N}_{2}$-fixing cyanobacterium Candidatus atelocyanobacterium thalassa sublineages. J. Phycol. 38, 42-49. doi:10.1111/jpy.12505.

Turk-Kubo, K. A., Karamchandani, M., Capone, D. G., and Zehr, J. P. (2014). The paradox of marine heterotrophic nitrogen fixation: Abundances of heterotrophic diazotrophs do not account for nitrogen fixation rates in the Eastern Tropical South Pacific. Environ. Microbiol. 16, 3095-3114. doi:10.1111/1462-2920.12346.

van Ruth, P. D., Patten, N. L., Doubell, M. J., Chapman, P., Rodriguez, A. R., and Middleton, J. F. (2018). Seasonal- and event-scale variations in upwelling, enrichment and primary productivity in the eastern Great Australian Bight. Deep. Res. Part II Top. Stud. Oceanogr. 157-158, 36-45. doi:10.1016/j.dsr2.2018.09.008.

Wang, Y., Naumann, U., Wright, S. T., \& Warton, D. I. (2012). Mvabund- an R package for model-based analysis of multivariate abundance data. Methods in Ecology and Evolution, 3(3), 471-474. https://doi.org/10.1111/j.2041-210X.2012.00190.x

Wang, W. L., Moore, J. K., Martiny, A. C., and Primeau, F. W. (2019). Convergent estimates of marine nitrogen fixation. Nature 566, 205-211. doi:10.1038/s41586-019-0911-2.

Wannicke, N., Benavides, M., Dalsgaard, T., Dippner, J. W., Montoya, J. P., and Voss, M. (2018). New perspectives on nitrogen fixation measurements using 15N2 gas. Front. Mar. Sci. 5, 1-10. doi:10.3389/fmars.2018.00120.

Ward, B. A., Dutkiewicz, S., Moore, C. M., and Follows, M. J. (2013). Iron, phosphorus, and nitrogen supply ratios define the biogeography of nitrogen fixation. Limnol. Oceanogr. 58, 2059-2075. doi:10.4319/1o.2013.58.6.2059.

Warthmann, R., Vasconcelos, C., Sass, H., and McKenzie, J. A. (2005). Desulfovibrio brasiliensis sp. nov., a moderate halophilic sulfate-reducing bacterium from Lagoa Vermelha (Brazil) mediating dolomite formation. Extremophiles 9, 255-261. doi:10.1007/s00792-005-0441-8.

Watkins-Brandt, K. S., Letelier, R. M., Spitz, Y. H., Church, M. J., Böttjer, D., and White, A. E. (2011). Addition of inorganic or organic phosphorus enhances nitrogen and carbon fixation in the oligotrophic North Pacific. Mar. Ecol. Prog. Ser. 432, 17-29. doi:10.3354/meps09147. 
1169

1170

1171

1172

1173

1174

1175

1176

1177

1178

1179

1180

1181

1182

1183

1184

1185

1186

1187

1188

1189

1190

1191

1192

1193

1194

1195

1196

1197

1198

1199
Weber, S. C., Carpenter, E. J., Coles, V. J., Yager, P. L., Goes, J., and Montoya, J. P. (2017). Amazon River influence on nitrogen fixation and export production in the western tropical North Atlantic. Limnol. Oceanogr. 62, 618-631. doi:10.1002/lno.10448.

White, A. E., Granger, J., Selden, C., Gradoville, M. R., Potts, L., Bourbonnais, A., Fulweiler R. W., Knapp A. N., Mohr W., Moisander P. H., Tobias C. R., Caffin M., Wilson S. T., Benavides M., Bonnet S., Mulholland M. R., Chang B. X. (2020). A critical review of the $15 \mathrm{~N} 2$ tracer method to measure diazotrophic production in pelagic ecosystems. Limnol. Oceanogr. Methods. doi:10.1002/lom3.10353.

Wilson, S. T., Bottjer, D., Church, M. J., and Karl, D. M. (2012). Comparative Assessment of Nitrogen Fixation Methodologies, Conducted in the Oligotrophic North Pacific Ocean. Appl. Environ. Microbiol. 78, 6516-6523. doi:10.1128/AEM.01146-12.

Zani, S., Mellon, M. T., Collier, J. L., and Zehr, J. P. (2000). Expression of nifH genes in natural microbial assemblages in Lake George, New York, detected by reverse transcriptase PCR. Appl. Environ. Microbiol. 66, 3119-3124. doi:10.1128/AEM.66.7.3119-3124.2000.

Zehr, J. P., Carpenter, E. J., and Villareal, T. A. (2000). New perspectives on nitrogen-fixing microorganisms in tropical and subtropical oceans. Trends Microbiol. 8, 68-73. doi:10.1016/S0966-842X(99)01670-4.

Zehr, J. P., Jenkins, B. D., Short, S. M., and Steward, G. F. (2003). Nitrogenase gene diversity and microbial community structure: a cross system comparison. Environ. Microbiol. 5, 539-554.

Zehr, J. P., and Kudela, R. M. (2011). Nitrogen Cycle of the Open Ocean: From Genes to Ecosystems. Ann. Rev. Mar. Sci. 3, 197-225. doi:10.1146/annurev-marine-120709-142819.

Zehr, J. P., and McReynolds, L. A. (1989). Use of degenerate oligonucelotides for amplification of the nifH gene from the marine cyanobacterium Trichodemium thiebautii. Appl. Environ. Microbiol. 55, 2522-2526.

Zehr, J. P., Mellon, M. T., Zani, S., and York, N. (1998). New Nitrogen-Fixing Microorganisms Detected in Oligotrophic Oceans by Amplification of Nitrogenase (nifH) Genes. Appl. Environ. Microbiol. 64, 3444-3450.

Zehr, J. P., and Turner, P. J. (2001). Nitrogen Fixation: Nitrogenase Genes and Gene Expression. Methods Microbiol. 30, 271-286. 


\section{Figure 1}

Sampling locations within Spencer Gulf and the adjacent continental shelf waters.

Samples were collected from the Kangaroo Island National Reference Station (Shelf), Spencer Gulf mouth (Mouth), south western edge (S-Gulf), mid western edge (M-Gulf), and northern Spencer Gulf (N-Gulf), with ocean bathymetry shown as a colour chart generated using Ocean Data View (Schlitzer, 2018).

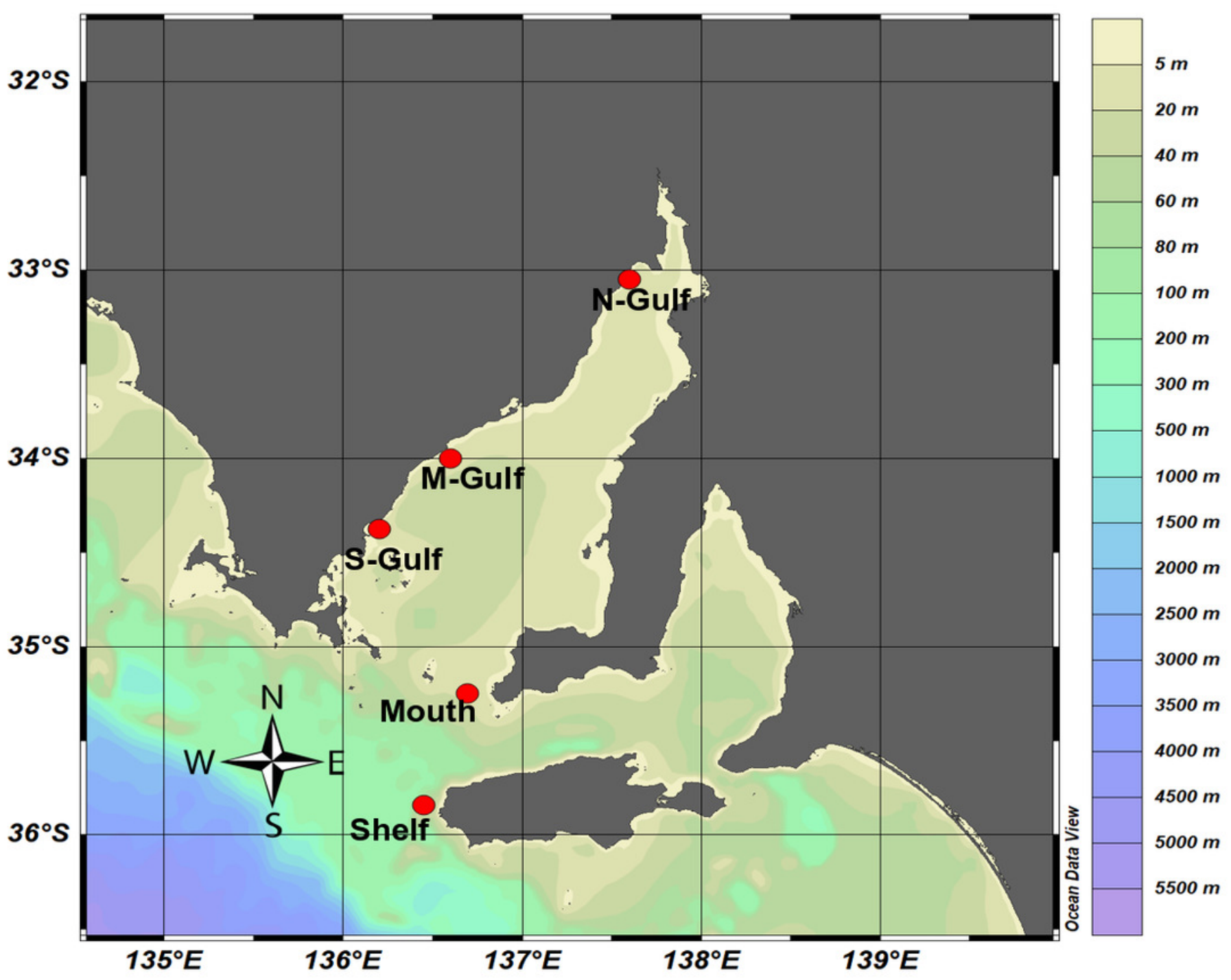


Figure 2

Biological $\mathrm{N}_{2}$ fixation rates measured during Austral autumn and summer in south Australian coastal waters.

Rates have been corrected to account for the incomplete dissolution of the ${ }^{15} \mathrm{~N}_{2}$ gas bubble (see Methods). Error bars represent the standard deviation about the mean $(n=3)$.

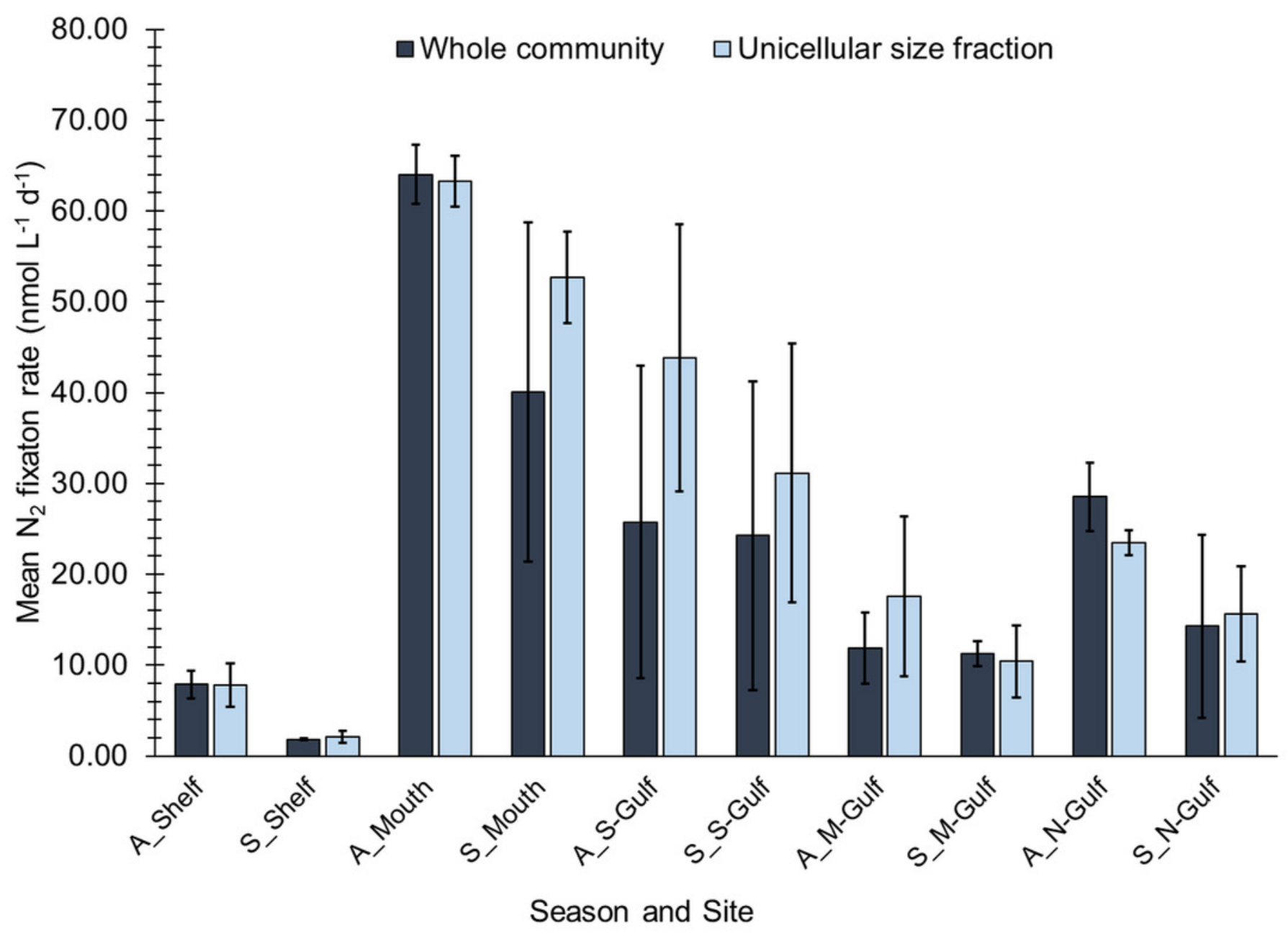


Figure 3

Relative abundance of the top 25 nifH OTUs and their taxonomic assignment (closest representative) detected within south Australian coastal waters during Austral autumn (A_) and summer (S_).

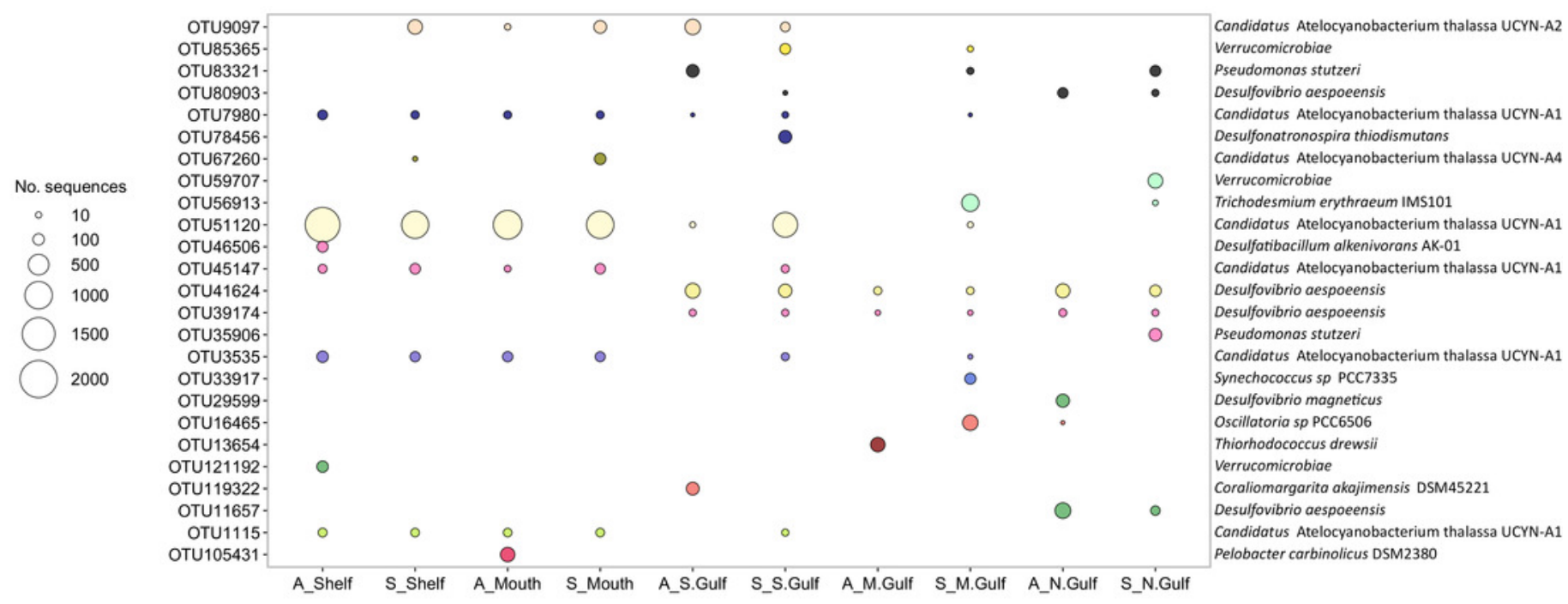


Figure 4

Mean qPCR derived abundances of UCYN-A1 and UCYN-A2 in south Australian coastal waters $(n=3)$.

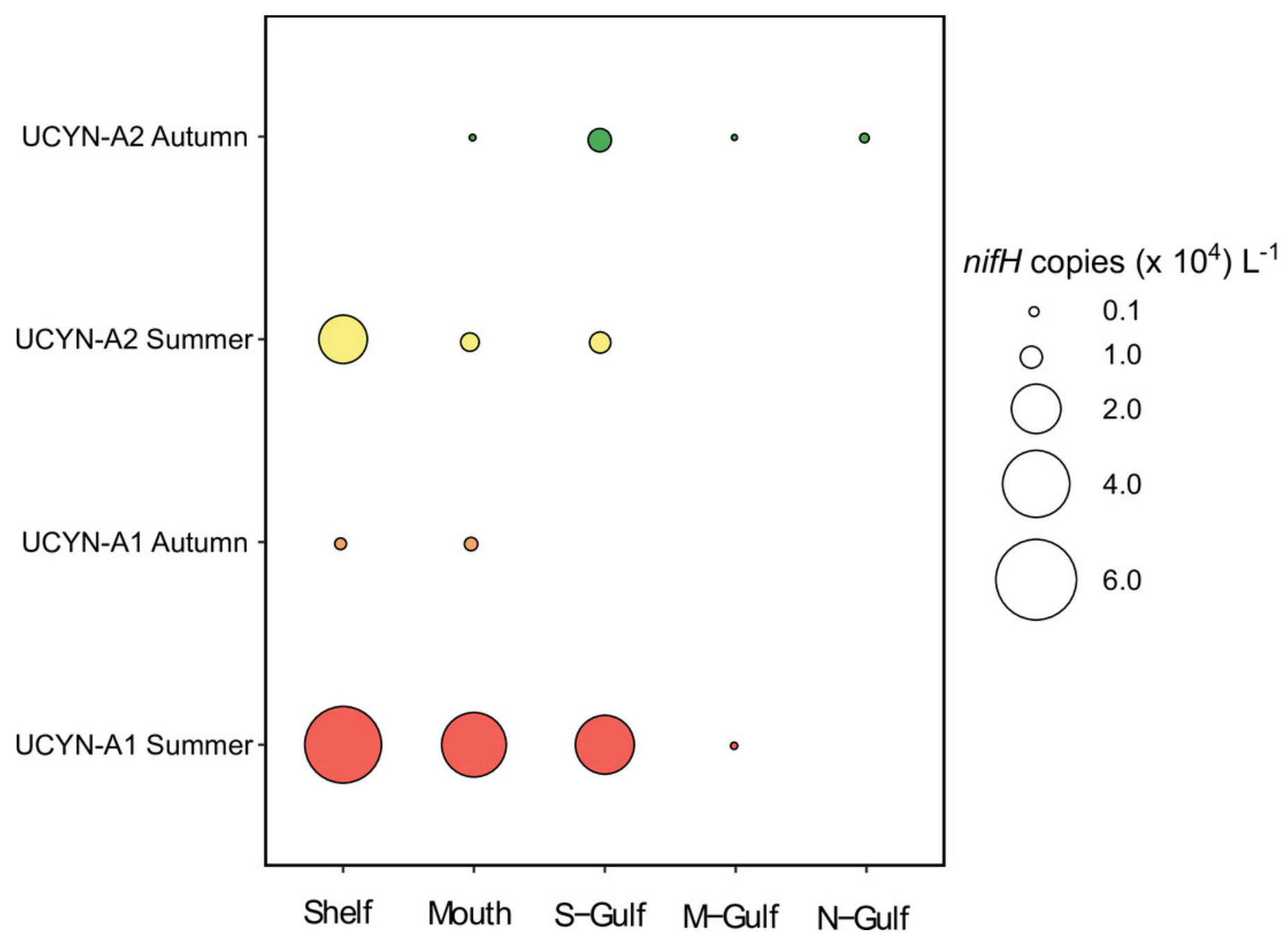




\section{Table $\mathbf{1}$ (on next page)}

Physico-chemical metadata associated with each sampling site.

Abbreviations: $\mathrm{A}=$ Autumn, $\mathrm{S}=$ Summer; Temp. = sea surface temperature; $\mathrm{PC}=$ particulate carbon; $\mathrm{PN}=$ particulate nitrogen. Sampling Time refers to the local time at the point of sample collection (Australian Eastern Standard Time). 


\begin{tabular}{|l|l|l|l|l|l|l|l|l|}
\hline Sample & $\begin{array}{l}\text { Sampling } \\
\text { Time }\end{array}$ & $\begin{array}{l}\mathrm{Temp} . \\
\left({ }^{\circ} \mathrm{C}\right)\end{array}$ & Salinity & $\begin{array}{l}\mathrm{NO}_{3} / \mathrm{NO}_{2} \\
(\mu \mathrm{M})\end{array}$ & $\begin{array}{l}\mathrm{PO}_{4} \\
(\mu \mathrm{M})\end{array}$ & $\begin{array}{l}\mathrm{SiO}_{4} \\
(\mu \mathrm{M})\end{array}$ & $\begin{array}{l}\mathrm{PC} \\
(\mu \mathrm{g})\end{array}$ & $\mathrm{PN}(\mu \mathrm{g})$ \\
\hline A_Shelf & $14: 30$ & 18.9 & 36.0 & 0.04 & 0.03 & 0.22 & 373 & 50.3 \\
\hline A_Mouth & $8: 00$ & 18.7 & 36.0 & 0.02 & 0.06 & 0.36 & 377.8 & 53.2 \\
\hline A_S-Gulf & $15: 00$ & 18 & 37.0 & 0.01 & 0.01 & 0.25 & 419.6 & 54.6 \\
\hline A_M-Gulf & $7: 30$ & 18.8 & 37.7 & 0.01 & 0.02 & 0.52 & 341.7 & 37.8 \\
\hline A_N-Gulf & $16: 00$ & 20.1 & 40.0 & 0.04 & 0.03 & 1.1 & 389.9 & 47.9 \\
\hline S_Shelf & $6: 30$ & 18.7 & 36.0 & 0.02 & 0.08 & 0.24 & 1184.2 & 36.7 \\
\hline S_Mouth & $9: 00$ & 19.6 & 36.0 & 0.01 & 0.04 & 0.24 & 762.7 & 44.6 \\
\hline S_S-Gulf & $15: 50$ & 22.3 & 36.5 & 0.03 & 0.02 & 0.52 & 376.8 & 45.5 \\
\hline S_M-Gulf & $7: 55$ & 21.1 & 36.9 & 0.03 & 0.05 & 0.53 & 755.5 & 62.8 \\
\hline S_N-Gulf & $16: 00$ & 23.1 & 40.3 & 0.04 & 0.02 & 0.39 & 342.3 & 42.8 \\
\hline
\end{tabular}

1 